\title{
Cesium, Potassium, and Sodium Tetraphenylborate Solubility In Salt Solution
}

by

D. J. McCabe

Westinghouse Savannah River Company

Savannah River Site

Aiken, South Carolina 29808

DOE Contract No. DE-AC09-96SR18500

This paper was prepared in connection with work done under the above contract number with the U.S.

Department of Energy. By acceptance of this paper, the publisher and/or recipient acknowledges the U.S. Government's right to retain a nonexclusive, royalty-free license in and to any copyright covering this paper, along with the right to reproduce and to authorize others to reproduce all or part of the copyrighted paper. 


\section{DISCLAIMER}

This report was prepared as an account of work sponsored by an agency of the United States Government. Neither the United States Government nor any agency thereof, nor any of their employees, makes any warranty, express or implied, or assumes any legal liability or responsibility for the accuracy, completeness, or usefulness of any information, apparatus, product, or process disclosed, or represents that its use would not infringe privately owned rights. Reference herein to any specific commercial product, process, or service by trade name, trademark, manufacturer, or otherwise does not necessarily constitute or imply its endorsement, recommendation, or favoring by the United States Government or any agency thereof. The views and opinions of authors expressed herein do not necessarily state or reflect those of the United States Government or any agency thereof.

This report has been reproduced directly from the best available copy.

Available to DOE and DOE contractors from the Office of Scientific and Technical Information, P. O. Box 62, Oak Ridge, TN 37831; prices available from (423) 576-8401.

Available to the public from the National Technical Information Service, U. S. Department of Commerce, 5285 Port Royal Road, Springfield, VA 22161. 


\section{DISCLAIMER}

Portions of this document may be illegible electronic image products. Images are produced from the best available original document. 
WSRC-TR-96-0384

Revision 0

Keywords: In-Tank

Precipitation,

Tetraphenylborate

Retention: Permanent

Cesium, Potassium, and Sodium Tetraphenylborate Solubility in salt solution (U)

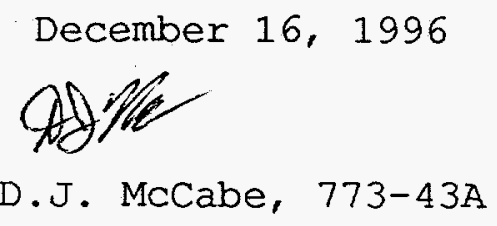

$\frac{\text { Samel }}{\text { Authorized Derivative classifier }}$

$\frac{\text { Samel D. Fink, Growp Manager }}{\text { Authorized Reviewing Official }}$

Savannah River Technology Center Westinghouse Savannah River Company Aiken, SC 29808 


\section{Summary}

Use of sodium tetraphenylborate to precipitate cesium in the InTank Precipitation (ITP) process results in the potential for benzene formation. Using lesser amounts of the chemical reduces the potential for forming benzene. The resulting lower flammability risk increases the safety margin for operations. This report documents studies of the solubility of cesium, potassium, and sodium tetraphenylborate. Increased understanding of the solubility allows reduced usage.

- The solubility product constant $\left(K_{s p}\right)$ of potassium tetraphenylborate (KTPB) determined in this task agrees with that observed in previous published studies.

- The solubility product constant of CsTPB has been determined, and agrees with the 1983 In-Tank Demonstration data.

- The solubility of CsTPB increases approximately 10-fold with a temperature rise from 25 to $65^{\circ} \mathrm{C}$.

- The solubility product constant of CsTPB determined in this task is approximately $10 \%$ of that observed in published studies. The discrepancy is due to differences in the $\mathrm{K}: \mathrm{Cs}$ ratio.

- The ratio of potassium to cesium impacts the solubility of CsTPB in salt solutions. More research is needed to quantify the effect.

- At $<1.5 \mathrm{M}$ sodium ion concentration, the CsTPB precipitation reaction is complete in less than 24 hours for stoichiometric additions of $\mathrm{TPB}^{-}$at $25^{\circ} \mathrm{C}$.

- Above $1.5 \mathrm{M}$ sodium ion concentration, the CsTPB precipitation reaction time can reach 160 hours at $25^{\circ} \mathrm{C}$. Addition of excess tetraphenylborate and higher temperature speeds the precipitation.

- Organics (i.e., phenol, benzene, phenylboric acid) do not impact the solubility of cesium in alkaline solutions with tetraphenylborate at the concentrations observed in ITP.

- If the activity coefficients are corrected for the variability in composition, the ratios of the anions (sulfate, nitrate, etc.) do not significantly impact the solubility of CsTPB in these solutions. 


\section{Introduction}

The ITP Process decontaminates radioactive waste in Tank $48 \mathrm{H}$ by precipitating cesium with sodium tetraphenylborate (NaTPB) and adsorbing radioactive strontium on MST. In addition to the cesium, all of the potassium in the solution precipitates with the $\mathrm{TPB}^{-}$. The solids are separated from the salt solution by crossflow filters. The design basis for removal of radioactive materials is to achieve less than $30 \mathrm{nCi} / \mathrm{g}$ of $\mathrm{Cs}-137$ and less than $18 \mathrm{nCi} / \mathrm{g}$ of alpha emitters in the filtrate. The cesium removal requirement is achieved by the extremely low solubility of cesium tetraphenylborate. The use of the tetraphenylborate (TPB') ion for precipitation of radioactive cesium from High Level Waste (HLW) suffers from generation of benzene. To achieve the high decontamination factor, excess NaTPB is added to the solution to force the cesium out of solution. The "excess" TPB" concentration causes cesium to precipitate and restore equilibrium (Equation 1).

$\mathrm{CS}^{+}{ }_{(\mathrm{AQ})}+\mathrm{TPB}_{(\mathrm{AQ})}^{-} \quad \mathrm{K}_{\mathrm{I}} \quad \mathrm{CsTPB}_{(\mathrm{solid})} \quad$ Equation 1

Decreasing the excess NaTPB reduces the potential quantity of benzene produced. To decrease the concentration of NaTPB while maintaining the cesium decontamination factor requires an accurate description of the factors influencing the solubility cesium tetraphenylborate (CSTPB) and potassium tetraphenylborate (KTPB) . In support of the Defense Nuclear Facility Safety Board (DNESB) Recommendation 96-1 Implementation Plan, 1 High Level Waste Engineering requested a study of the solubility of tetraphenylborate salts of cesium and potassium. ${ }^{2}$

Previous equations used to calculate the CSTPB and NaTPB solubility ${ }^{3}$ were based on work by $\mathrm{E}$. Siska. ${ }^{4}$ These equations were not consistent with observations during testing and demonstration of the ITP process. Further testing has been completed to determine the equations that more accurately predict the solubility of CSTPB, NaTPB, and KTPB.

The equilibrium solubility product constant of CsTPB can be described by equation 2 .

$\mathrm{K}_{\mathrm{sp}(\mathrm{Cs})}=\left[\begin{array}{lllllll}\left.\mathrm{Cs}^{+}\right] & {\left[\mathrm{TPB}^{-}\right] \times} & \left(\gamma_{\mathrm{Cs}}\right) \times & \left(\gamma_{\mathrm{TPB}}\right) & \text { Equation } 2\end{array}\right.$

Where $\left[\mathrm{Cs}^{+}\right]$and $\left[\mathrm{TPB}^{-}\right]$are the molar concentrations of the aqueous species and $\gamma_{C s}$ and $\gamma_{\text {TPB }}$ are the molality-scale activity coefficients The activity coefficients are described by the Debye-Hückle equation ${ }^{5}$ for dilute solutions, but must be adjusted for the ionic strength for more concentrated solutions $(>0.01 \mathrm{~m})$. One method for calculating the activity coefficients is use of a computer software model, Environmental Simulation Program by OLI, Inc. 
This software utilizes a mathematical framework to derive the thermodynamic properties of aqueous solutions.

\section{Experimental}

Simulated salt solutions were prepared at $4.7 \mathrm{M}\left[\mathrm{Na}^{+}\right]$(Table 1 ). The standard solution was diluted with deionized water to achieve the desired sodium concentration for specific tests. For solutions containing less than $1.0 \mathrm{M}\left[\mathrm{Na}^{+}\right]$, aliquots of cesium nitrate and potassium nitrate solutions were added to maintain the concentrations above the solubility product. The ratio of cesium to potassium remained constant (at $1: 62$ ) unless otherwise specified. Simulants for NaTPB solubility were prepared without cesium or potassium nitrate. Simulants were also prepared from sodium sulfate for comparison to literature data. Cesium nitrate and potassium nitrate were also added to these solutions. Sodium tetraphenylborate (Aldrich, 99+官) solution $(0.5 \mathrm{M}, 4 / 2 / 96$ ITP Benzene Tests Solution $A$ ) was added to the salt solutions and the samples were continuously agitated at 150-200 rpm for 24 hours (unless otherwise specified in kinetics tests). Solid sodium tetraphenylborate (Aldrich, 99+\%) was used for the NaTPB solubility tests.

$\begin{array}{lc}\text { Table } 1.4 .7 \mathrm{M}[\mathrm{Na}] & \text { Aqueous salt solution } \\ \text { Component } & \text { Cencentration (M) } \\ \mathrm{Na}_{2} \mathrm{SO}_{4} & 0.14 \\ \mathrm{NaNO}_{2} & 0.66 \\ \mathrm{NaNO}_{3} & 0.74 \\ \mathrm{NaOH} & 2.68\left(1.4 \mathrm{M} \text { free } \mathrm{OH}^{-}\right) \\ \mathrm{KNO}_{3} & 0.013 \\ \mathrm{Na}_{2} \mathrm{CO}_{3} \cdot \mathrm{H}_{2} \mathrm{O} & 0.17 \\ \mathrm{Al}_{\left(\mathrm{NO}_{3}\right)_{3} \cdot 9 \mathrm{H}_{2} \mathrm{O}} & 0.32 \\ \mathrm{CsNO} & 0.00021\end{array}$

Selected organic compounds present in decomposed tetraphenylborate slurry were added to one simulated salt solution to examine their impact. The solution was diluted to $0.25 \mathrm{M}\left[\mathrm{Na}^{+}\right]$and $1000 \mathrm{mg} / \mathrm{L}$ each of phenol, phenylboric acid, and benzene were added. The phenylboric acid and phenol completely dissolved.

A simulated salt solution containing different ratios of anions were also prepared to examine the effect of anion composition. The solution did not contain any divalent anions (Table 2). The solution was prepared at $5.6 \mathrm{M}[\mathrm{Na}+]$ and diluted to the desired concentration $\left(0.25 \mathrm{M}\left[\mathrm{Na}^{+}\right]\right)$prior to NaTPB addition. 
Table 2. $5.6 \mathrm{M}$ [Na+] High Hydroxide Salt Solution

$\begin{array}{lc}\text { Component } & \text { Concentration (M) } \\ \mathrm{NaNO}_{2} & 0.30 \\ \mathrm{NaOH} & 5.3 \quad\left(2.26 \mathrm{M} \text { free } \mathrm{OH}^{-}\right) \\ \mathrm{KNO}_{3} & 0.015 \\ \mathrm{Al}\left(\mathrm{NO}_{3}\right)_{3} \cdot 9 \mathrm{H}_{2} \mathrm{O} & 0.76 \\ \mathrm{CsNO}_{3} & 0.00024\end{array}$

Temperature of the slurries was maintained using an orbital shaking water bath. Temperature of the water was recorded and found to vary by $\pm 2.5^{\circ} \mathrm{C}$. All CSTPB and KTPB samples were filtered with 0.2 micron Nalgene $e^{\mathrm{TM}}$ filters. The NaTPB samples were filtered with 0.45 micron Nalgen ${ }^{\text {TM }}$ filters. For the elevated temperature tests, samples were filtered quickly $(<2$ minutes) and ultrapure water was added to maintain the solubility of the compounds as it cooled. The ultrapure water was checked by Inductively Coupled Plasma - Mass Spectroscopy (ICP-MS) and found to not contain measurable amounts of $\mathrm{K}$, Cs, or $B$.

All samples were analyzed by ICP-MS. The boron purity of the NaTPB was examined by addition of NaTPB to a $1.0 \mathrm{M}$ potassium nitrate solution. Less than $0.064 \%$ of the added boron was found soluble after precipitation of KTPB, indicating that boron analysis could determine the TPB concentration.

Blank samples (i.e., no NaTPB added) were analyzed for with each series of samples to confirm the accuracy of the analyses. Also, a series of blind standards were prepared and analyzed. The blind standard was prepared from the same batch of reagent grade chemicals as the simulant. The calculated versus measured concentrations were within the expected error of $\sim 10 \%$ (Figures 1 and 2).

Densities of the solutions after NaTPB addition were determined over a range of concentrations (Table 3). The amount of NaTPB added to these solutions was stoichiometrically equivalent to the concentration of potassium and was not saturated with NaTPB. A pipetter was used to measure the volume of salt solution and the pipetter was checked with a weighed amount of deionized water to ensure a consistent volume delivery. The densities were measured in triplicate. The molality (m) of the solutions were then calculated from the density (Table 3, Figure 3) and composition.

Table 3. Density of Salt Solutions $\left(T=25{ }^{\circ} \mathrm{C}\right)$

$\begin{array}{lll}\mathrm{Na}(\mathrm{M}) & \text { density }(\mathrm{g} / \mathrm{mL}) & \mathrm{Na}(\mathrm{m}) \\ 4.7 & 1.2179 & 5.2 \\ 1.4 & 1.0715 & 1.5 \\ 0.47 & 1.0248 & 0.47 \\ 0.14 & 1.0144 & 0.14 \\ 0.047 & 1.0063 & 0.047\end{array}$




\section{Results and Discussion}

\section{Precipitation Kinetics}

The precipitation of CsTPB in $0.28 \mathrm{M}$ sodium ion salt solution is complete in less than 24 hours at room temperature (Table 4, Figure 4) with stoichiometric quantities of potassium and tetraphenylborate ions $( \pm 1 \%)$. The cesium concentration increased after 216 hours and is likely attributable to variability in the experimental procedure or the analysis. The standard deviations calculated for this test reflect the variance for replicate experiments. Temperature, homogeneity of samples, pipette volumes, and analytical scatter contribute to this variance. The cesium concentration is near the detection limit of the instrument, contributing to the variability of the data. A longer test is needed to confirm that the results are due to experimental variability.

Table 4. Precipitation Kinetics in $0.28 \mathrm{M}\left[\mathrm{Na}^{+}\right]$at $25{ }^{\circ} \mathrm{C}$

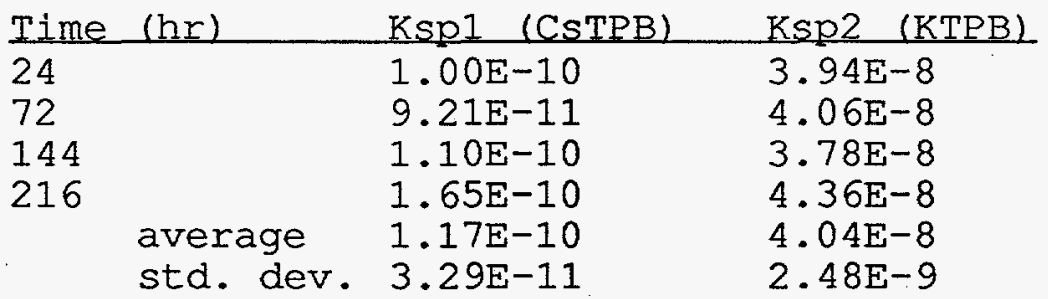

At $4.7 \mathrm{M}$ sodium ion salt solution with near-stoichiometric addition of $\mathrm{TPB}^{-}$, the reaction was nearly complete after approximately 160 hours (Figure 5) at $25^{\circ} \mathrm{C}$. The solution contained less TPB than the stoichiometric amount of potassium $\left(0.198 \mathrm{mM}\left[\mathrm{K}^{+}\right]\right.$vs. $\left.0.145 \mathrm{mM}\left[\mathrm{TPB}^{-}\right]\right)$due to tramp potassium in the chemicals used to prepare the simulant, yielding a conservative estimate of the reaction time. This caused a higher cesium solubility in these samples, consistent with a shift in the equilibrium. This data indicates that the precipitation reaction at near-stoichiometric conditions in high ionic strength solutions can be very slow. Further work is needed to precisely define the precipitation kinetics with excess TPB ${ }^{-}$.

At $4.7 \mathrm{M}$ sodium ion salt solution at $65^{\circ} \mathrm{C}$ with nearstoichiometric addition of $\mathrm{TPB}^{-}$, the reaction was complete in 24 hours (Figure 6). The results indicate that the time required for precipitation can be significantly reduced by heating the solution; however, the solubility also increases with temperature.

At $1.41 \mathrm{M}\left[\mathrm{Na}^{+}\right]$and $25^{\circ} \mathrm{C}$, the reaction was complete in less than four hours (Figure 7). The cesium concentration was below the detection limit when the first sample was collected, indicating a very rapid reaction. Eurther work is needed to quantify the impact of excess $\mathrm{TPB}^{-}$on the precipitation rate. 


\section{Equilibrium constant Calculation}

Equations for the cation $\left(\mathrm{K}^{+}, \mathrm{Cs}^{+}, \mathrm{Na}^{+}\right)$and anion (TPB) activity coefficients in salt solution have been derived from the Environmental Simulation Program by OLI, Inc. The equations were then used as a basis for experiments. To determine if the activity coefficients were valid, the solubility of the tetraphenylborate salts was determined over a range of ionic strengths. The equations were then used to determine $\mathrm{K}_{\mathrm{sp}}$ for each species. The activity coefficient equations were confirmed by the observation that the $\mathrm{K}_{\mathrm{sp}}$ was relatively constant over the range of ionic strengths. To determine the activity coefficients, the molality and ionic strength of the solutions must be calculated.

The activity coefficient equations from the OLI software for sodium, cesium, and potassium ions are valid with 'standard' salt solution up to $5 \mathrm{M}$ sodium ion concentration (Figure 8). Small variations in the anion composition will not significantly impact the activity coefficient. The activity coefficient for the tetraphenylborate ion was also derived from the OLI software, based on the Siska data." The Siska data was collected in sodium sulfate solution up to $2.0 \mathrm{M}$ in sodium ion. The OLI software was used to calculate the activity coefficient to $2.0 \mathrm{M}$ sodium sulfate, and then was extrapolated to $5 \mathrm{M}$ sodium ion by plotting the data and fitting a curve (Eigure 9). The manual curve fitting was required because the OLI software under predicted the solubility of CSTPB at $5 \mathrm{M}$ sodium ion concentration. The extrapolated activity coefficient was then used as a guide and was confirmed by experiment. The TPB activity coefficient equation was confirmed by determining the KTPB and NaTPB solubilities at high ionic strength because the CsTPB solubility was difficult to measure directly. Further work is needed to verify the activity coefficient equations at intermediate ionic strength $\left(2-4 \mathrm{M} \mathrm{Na}^{+}\right)$.

$\mathrm{Cs}^{+}$activity coefficient $\left(\gamma_{\mathrm{cs}}\right)=0.0258 \mathrm{I}_{\mathrm{m}}{ }^{2}-0.160 \mathrm{I}_{\mathrm{m}}+0.783$

$\mathrm{K}^{+}$activity coefficient $\left(\gamma_{\mathrm{K}}\right)=0.0284 \mathrm{I}_{\mathrm{m}}{ }^{2}-0.219 \mathrm{I}_{\mathrm{m}}+0.777$

$\mathrm{Na}^{+}$activity coefficient $\left(\gamma_{\mathrm{Na}}\right)=0.00880 \mathrm{I}_{\mathrm{m}}{ }^{2}-0.0701 \mathrm{I}_{\mathrm{m}}+0.701$

$\mathrm{TPB}^{-}$activity coeff. $\left(\gamma_{\mathrm{TPB}}\right)=1.91 \mathrm{I}_{\mathrm{m}}{ }^{3}-4.54 \mathrm{I}_{\mathrm{m}}{ }^{2}+5.48 \mathrm{I}_{\mathrm{m}}+0.712$

where the $I_{m}$ is the molality-scale ionic strength of the solution.

The ionic strength of any solution is calculated from the following equation:

$$
I_{m}=0.5\left\{\left(\mathrm{Z}_{\mathrm{a}}^{2} \times \mathrm{m}_{\mathrm{a}}\right)+\left(\mathrm{z}_{\mathrm{b}}^{2} \times \mathrm{m}_{\mathrm{b}}\right)+\left(\mathrm{z}_{\mathrm{c}}{ }^{2} \times \mathrm{m}_{\mathrm{c}}\right) \ldots\right\}
$$

where $\mathrm{z}$ is the ionic charge of the ions and $\mathrm{m}$ is the molal concentration (moles/1000 g solvent). For the radioactive waste 
tests described in this work, the density and anion composition $\left(\left[\mathrm{CO}_{3}^{-2}\right],\left[\mathrm{SO}_{4}^{-2}\right]\right)$ of the solutions were estimated to permit calculation of the molality. The density of salt solutions used in these experiments was determined. The following equation was fitted to the data to estimate the density $(\mathrm{g} / \mathrm{mL})$ of the salt solutions at intermediate concentrations (Eigure 3 ).

$\partial=0.0452\left[\mathrm{Na}^{+}\right]+1.006$ where $\left[\mathrm{Na}^{+}\right]$is the molar concentration.

The molality (m) is calculated from the molarity (M) with the following equation:

$m=M /\{\partial-($ wt. dissolved solids/1000) $\}$

where the weight of the dissolved solids is the sum of the weight of all dissolved solids in 1 I of salt solution.

To obtain the ion solubility, the activity coefficient is then used in the solubility equilibrium equation:

$[\mathrm{CS}] \mathrm{sol}=\mathrm{K}_{\mathrm{sp}, 1} /\left\{\left[\mathrm{TPB}^{-}\right] \times\left(\gamma_{\mathrm{Cs}}\right) \times\left(\gamma_{\mathrm{TPB}}\right)\right\}$

where the soluble [TPB'] is expressed in molarity. A similar equation is used to determine the potassium and tetraphenylborate ion solubilities.

$\mathrm{K}_{\mathrm{sp}, 1}(\mathrm{CsTPB})=1.03 \mathrm{E}-10 \mathrm{M}^{2}$ at $25^{\circ} \mathrm{C}$

$\mathrm{K}_{\mathrm{sp}, 2}(\mathrm{KTPB})=5.03 \mathrm{E}-8 \mathrm{M}^{2}$ at $25^{\circ} \mathrm{C}$.

$\mathrm{K}_{\mathrm{sp}, 3}(\mathrm{NaTPB})=0.62 \mathrm{M}^{2}$ at $25^{\circ} \mathrm{C}$.

For comparison of the OLI-derived equations to experimental results, the NaTPB solubility was determined in salt solution (Table 5). The sodium concentration in Table 5 is the final value including the contribution from salt solution and dissolved NaTPB. The NaTPB equilibrium constant $\left(\mathrm{K}_{\mathrm{sp}, 3}\right)$ was estimated to be 0.62 , and the TPB $^{-}$activity coefficient was calculated. The sodium activity coefficient was calculated using the equation above. The value for $K_{s p, 3}(0.62)$ was selected, rather than the average value, because the sodium activity coefficient was based on a model of the salt solution and is only valid for low concentrations of NaTPB. At high concentration of NaTPB, the equation for the sodium activity may vary. This is not a concern for ITP operations because the condition with high concentration of NaTPB $(>0.1 \mathrm{M})$ is not encountered. The results indicate good agreement between the OLI data and the experimental results (Eigure 10). The density of the NaTPB-saturated salt solution was also determined (Figure 11). 
Table 5. NaTPB solubility in salt solution

\begin{tabular}{|c|c|c|c|}
\hline Iotal [Na] (M) & {$[T P B](M)$} & Density $(\mathrm{g} / \mathrm{mL})$ & KSP3 (NaTPB) \\
\hline 4.23 & 0.0016 & 1.179 & 0.622 \\
\hline 2.39 & 0.043 & 1.091 & 0.875 \\
\hline 1.05 & 0.111 & 1.060 & 0.299 \\
\hline 0.633 & 0.163 & 1.056 & 0.237 \\
\hline 0.473 & 0.332 & 1.036 & 0.381 \\
\hline
\end{tabular}

average: 0.48

\section{Temperature Dependence}

The temperature dependence of the solubility product constants was derived for CSTPB and KTPB. The dependence of the KTPB solubility with temperature agrees with that of Siska ${ }^{4}$ (Figure 12). The variance of CsTPB solubility with temperature nearly parallels the Siska data, but is offset by the difference in solubility (Figure 13). The NaTPB solubility data (Figure 14) agrees with earlier results ${ }^{6}$ indicating only slight dependence of solubility with temperature. Equations for the equilibrium constants were derived from the experimental data and are valid from 25 to $65^{\circ} \mathrm{C}$ :

$\mathrm{K}_{\mathrm{sp}, 1}(\mathrm{CsTPB})=2.328 \mathrm{E}-11 \mathrm{e}^{(5.199 \mathrm{E}-2 \mathrm{~T})}$

$\mathrm{K}_{\mathrm{sp}, 2}(\mathrm{KTPB})=7.81 \mathrm{E}-9 \mathrm{e}^{(6.30 \mathrm{E}-2 \mathrm{~T})}$

$K_{\mathrm{sp}, 3}(\mathrm{NaTPB})=0.439 \mathrm{e}^{(1.39 \mathrm{E}-2 \mathrm{~T})}$

The values for $K_{s p, 1}$ and $K_{s p, 2}$ were derived from a series of experiments over a range of concentration of salt solution. The data are more erratic at high temperature than at ambient temperature (i.e., $K_{s p}$ is more variable throughout the range of ionic strengths). This larger variance is probably due to experimental variability during handling due to additional dilutions. The average values for $\mathrm{K}_{\mathrm{sp}, 1}$ and $\mathrm{K}_{\mathrm{sp}, 2}$, and the standard deviation were calculated. Additional data for KTPB, CsTPB, and NaTPB, at elevated temperatures are shown in Table 8 .

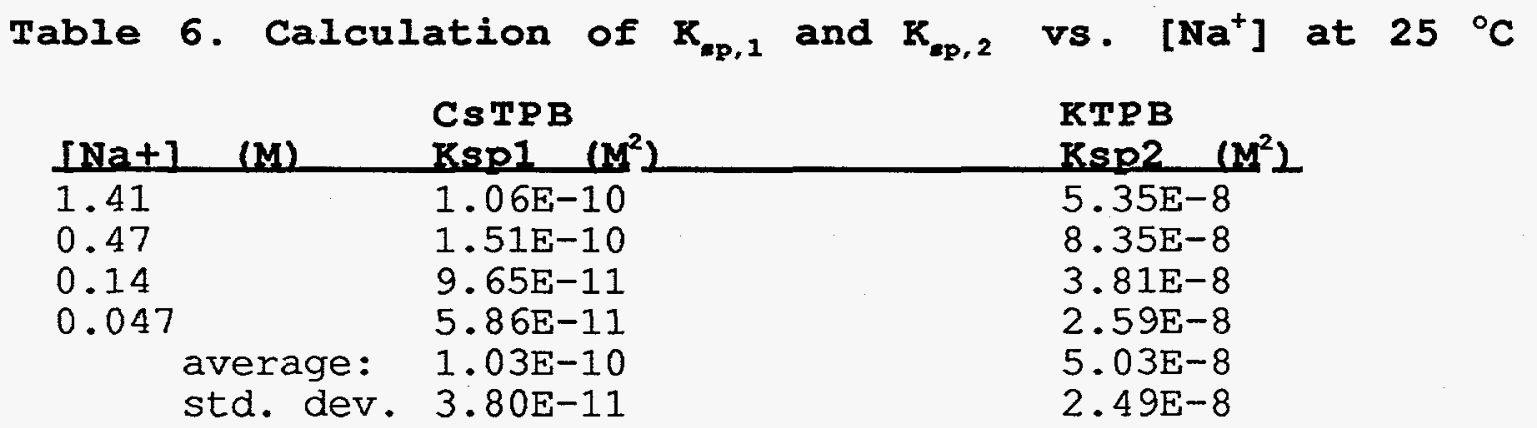


Table 7. Calculation of $\mathrm{K}_{\mathrm{sp}, 1}$ and $\mathrm{K}_{\mathrm{sp}, 2}$ vs. $\left[\mathrm{Na}^{+}\right]$at $65{ }^{\circ} \mathrm{C}$

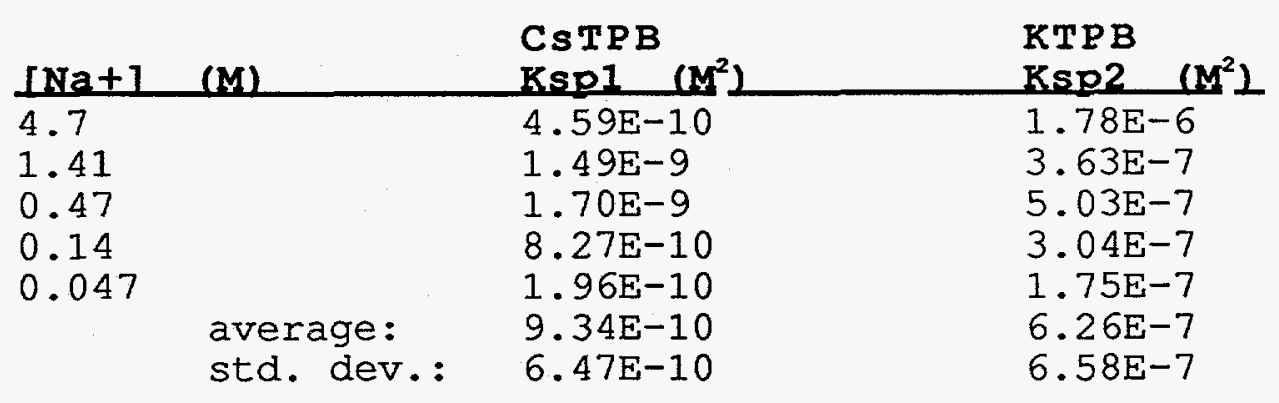

Table 8. Calculation of $\mathrm{k}_{\mathrm{sp}}$, at Elevated Temperatures

\begin{tabular}{lllll} 
& $\mathbf{T}\left({ }^{\circ} \mathbf{C}\right)$ & Nat & (M) & Ksp $\left(\mathbf{M}^{2}\right)$ \\
\hline KTPB & 50 & 0.47 & $7.52 \mathrm{E}-8$ \\
CSTPB & 50 & 0.47 & $1.90 \mathrm{E}-10$ \\
NaTPB & 65 & 2.388 & 1.08
\end{tabular}

Effect of Organics. Anions, and Potassium

The impact of organics, K:Cs ratio, and the composition of the anions was also determined (Table 9). The organics test utilized a $0.25 \mathrm{M}[\mathrm{Na}+]$ standard alkaline salt solution simulant and 1000 $\mathrm{mg} / \mathrm{L}$ each of benzene, phenol, and phenylboric acid. The composition of the anions was varied using a high hydroxide formulation substituting sodium hydroxide for the sodium sulfate and carbonate (Table 2). The results indicate that the impact of the organic and anionic components is minimal.

Table 9. Impact of Organics, Anions, and Potassium

\begin{tabular}{lll} 
& CsTPB & KTPB \\
Experiment & Ksp1 $\left(\mathbf{M}^{2}\right)$ & KsP2 $\left(\mathbf{M}^{2}\right)$ \\
\hline organics & $1.13 \mathrm{E}-10$ & $4.92 \mathrm{E}-8$ \\
high hydroxide & $1.32 \mathrm{E}-10$ & $5.02 \mathrm{E}-8$
\end{tabular}

For comparison to Siska' $\mathrm{s}^{4}$ experimental data, the activity coefficient equations determined using the OLI software were used to calculate the $\mathrm{K}_{\mathrm{sp}, 1}$ (CsTPB) and $\mathrm{K}_{\mathrm{sp}, 2}$ (KTPB) values (Table 10). The Siska data was collected in sodium sulfate solutions and the OLI software generated the activity coefficients based on ionic strength. This approach is self-consistent because the activity coefficients generated by the OLI program were derived from the the Siska data. This exercise demonstrates that the software and derived equations are consistent with the original data. 
Table 10. Calculation of $K_{x p, 1}$ and $K_{a p, 2}$ from Siska's Data

\begin{tabular}{llll} 
& & CsTPB & KTPB \\
INa+1 (M) & KsP1 $\left(M^{2}\right)$ & KsP2 $\left(M^{2}\right)$ \\
\hline 2.0 & $1.36 E-9$ & $2.77 E-8$ \\
0.7 & $9.64 E-10$ & $2.55 E-8$ \\
0.3 & $1.19 E-9$ & $2.80 E-8$ \\
0.05 & $8.84 E-10$ & $1.91 E-8$ \\
& & $1.10 E-9$ & $2.51 E-8$ \\
& average: & 10 & $4.14 E-9$
\end{tabular}

The average equilibrium constant for CsTPB from the Siska report ${ }^{4}$ is an order of magnitude higher than that observed in the current work $\left(1.03 \mathrm{E}-10 \mathrm{M}^{2}\right)$. The KTPB equilibrium constant determined in this study $\left(5.03 \mathrm{E}-8 \mathrm{M}^{2}\right)$ is similar to that observed by siska.

To examine the discrepancy between the two studies, two experiments were performed using $0.124 \mathrm{M}$ sodium sulfate solution $\left(0.25 \mathrm{M}\left[\mathrm{Na}^{+}\right]\right.$) and a mixture of potassium and cesium ions ( $\mathrm{Table}$ 11). Two ratios of $\mathrm{TPB}^{-}$to potassium were used to examine the impact of increased $\mathrm{TPB}^{-}$on the equilibrium condition. The CsTPB and KTPB equilibrium constants were determined (Table 11) and are nearly identical with those determined using salt solution $\left(\mathrm{K}_{\mathrm{sp}, 1}=\right.$ $1.03 \mathrm{E}-10 \mathrm{M}^{2} ; \mathrm{K}_{\mathrm{sp}, 2}=5.03 \mathrm{E}-8 \mathrm{M}^{2}$ ). The results suggest that the mixture of potassium and cesium ions may have an impact on the observed solubility of cesium, or that the Siska data or the activity coefficient are in error.

\begin{tabular}{lcc} 
Table 11. $\mathrm{K}_{\mathrm{sp}, 1}$ and $\mathrm{K}_{\mathrm{sp}, 2}$ & in Aqueous Sodium Sulfate \\
& $\mathrm{CsTPB}$ & $\mathrm{KTPB}$ \\
$\mathrm{TPB}: \mathrm{K}$ & $\mathrm{KSP1}\left(\mathrm{M}^{2}\right)$ & $\mathrm{KSP2}\left(\mathrm{M}^{2}\right)$ \\
\hline $1.25: 1$ & $1.43 \mathrm{E}-10$ & $3.92 \mathrm{E}-8$ \\
$1: 1$ & $1.77 \mathrm{E}-10$ & $4.39 \mathrm{E}-8$
\end{tabular}

An additional experiment, using $0.125 \mathrm{M}$ sodium sulfate solution with no added potassium, verifies the conclusion that the ratio of potassium to cesium influences the solubility. The resulting $\mathrm{K}_{\mathrm{sp}, 1}$ $=3.54 \mathrm{E}-9 \mathrm{M}^{2}$ is even higher than the Siska data (1.10E-9 $\left.\mathrm{M}^{2}\right)$ in pure sodium sulfate. The large excess of $\mathrm{TPB}^{-}$did not impact the equilibrium constants (Table 11), indicating that the reason for the discrepancy is not related to the presence of excess TPB. The system is well behaved and the data suggests that additional anionic $\mathrm{TPB}^{-}$only causes a shift in the equilibrium (Equation 1). Furthermore, previous equations that were used for calculating the solubility of CsTPB in salt solutions ${ }^{3}$ did not factor in the ionic strength but only described the solubility in terms of the molarity of sodium. Both the ionic strength and the potassium-tocesium ratio appear important to the $\mathrm{Cs}^{+}$solubility. More research into the influence of the ratio of potassium and cesium is needed 
to better predict the CsTPB solubility in solutions that contain high concentrations of potassium.

\section{Comparison to Radioactive raste}

Using the equations derived from the current work, the predicted cesium solubility can be compared with the observed solubility during the precipitate washing cycle of the 1983 In-Tank

Demonstration. ${ }^{2}$ It was assumed for these calculations that the Cs137 is 35 atom $\%$ of the total cesium present (Table 12). The measured concentration of $\mathrm{TPB}^{-}$was used for all calculations.

Table 12. Calculated vs. Observed Cs Radioactivity for 1983 In-Tank Demonstration

$\begin{array}{llccc}{\left[\mathrm{Na}^{+} \perp(\mathrm{M})\right.} & {\left[\mathrm{TPB}^{-}\right]} & \text {calculated } & \text { Cs } & \text { observed } \mathrm{Cs} \\ 5.1 & 0.0016 \mathrm{M} & 1.0(\mathrm{nCi} / \mathrm{g}) & 2.0(\mathrm{nCi} / \mathrm{g}) \\ 1.2 & 0.067 & 2.1 & 2.4 \\ 0.57 & 0.025 & 8.5 & 7.3 \\ 0.17 & 0.0088 & 43.5 & 28.0\end{array}$

Similarly, the cesium solubility during sampling and recent experiments using Tank $48 \mathrm{H}$ slurry (Table 13) can be compared. ${ }^{8}$ The sample from Tank $48 \mathrm{H}$ on December 28 (Table 13) is assumed to contain no remaining soluble (sodium) tetraphenylborate. To calculate the solubility of cesium, the solubility of KTPB was assumed to be the only source of soluble tetraphenylborate ion.

Table 13. Calculated vs. Observed Cs Radioactivity for PVT-1 Samples and Testing

exp't/sample $\left[\mathrm{Na}^{+} I(M) \quad[T P B=1(M)\right.$ calculated observed

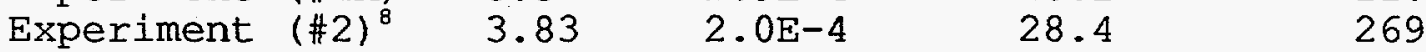

Tk $48 \mathrm{H}, 12 / 28 / 95 \quad 4.70 \quad 2.3 \mathrm{E}-5 * \quad 102 \quad 28$

*estimated concentration

The calculated cesium activities agree reasonably well with the observed cesium activity for the 1983 In-Tank Demonstration (Table 12). In Table 13, the two samples from PVT-1 testing are not self-consistent. This discrepancy suggests that the experiments were not at equilibrium or that the tetraphenylborate analysis is in error. It is likely that the PVT-1 test solutions were not at equilibrium due to the short mixing time ( $<2$ hours). Considering the approximation of tetraphenylborate concentration in this estimate, the analysis results agree reasonably well with the predicted value. 


\section{Conclusions}

Initial experiments to quantify the NaTPB excess required to achieve decontamination at ITP are complete. The cesium in these solutions was often below the detection limit of the instrument. The activity coefficient of tetraphenylborate ion at high ionic strength was verified by determining the sodium tetraphenylborate solubility. The system seems well behaved, and is not effected by organic compounds. The effect of anions can be mathematically compensated by using the ionic strength instead of the molar concentration of species in calculations.

The rate of precipitation can be slow, but appears to be complete within 160 hours at ambient temperature. Further testing to quantify the rate of precipitation with excess NaTPB is needed.

The equations and equilibrium constants derived from this work represent the best available data with salt solutions simulating the ITP process.

Further work is needed in the following areas:

- Evaluate the potassium to cesium ratio to better define the impact on both the equilibrium constant and on the rate of precipitation

- Examine the precipitation kinetics with excess $T^{-} B^{-}$to further quantify the time required for mixing in Tank $48 \mathrm{H}$

- Examine the mixing and addition rates on the rate of precipitation

\section{References}

3. L. Lee and L. Kilpatrick, DP-1636, "A Precipitation Process for Supernate Decontamination", November, 1982.

4. E. Siska, "The Solubility of Difficultly Soluble Tetraphenyl Borate Compounds, I. The Solubility of Potassium, Cesium, and Ammonium Tetraphenyl Borate", Magyar Kemiai Folyoirat, 82, 275 (1976).

5. P. Debye and E. Hückel, Physik. Z., 24, 185 (1923).

6. M.J. Barnes, R.A. Peterson, R.F. Swingle, and C.T. Reeves, "Sodium Tetraphenylborate Solubility and Dissolution Rates (U)", WSRC-TR-95-0092, March 7, 1995. 


\section{Ouality Assurance}

The experimental methods and results were recorded in laboratory notebooks

\section{Acknowledoements}

Analytical analyses were performed by Melton Bryant. These nonroutine analyses required considerable effort. Steve Serkiz provided assistance in developing the activity coefficient equations.

\section{Attachment}

Analytical data analyses ( 7 pages) 
Distribution:

H.H. Elder, 704-S

J.T. Carter, 704-25S

R.A. Jacobs, 241-121H

L.M. Papouchado, 773-A

P.L. Rutland, 241-152H

G.T. Wright, 773-A

B.L. Lewis, 703-H

E.W. Holtzscheiter, 773-A

A.S. Choi, 704-1T

M.C. Chandler, 703-H

N.F. Chapman, 512-11S

L.O. Dworjanyn, 779-2A

L.F. Landon, 704-T

R.E. Eibling, 704-T

C.T. Randall, 704-T

G.A. Taylor, 703-H

J.E. Marra, 704-56H

A.W. Wiggins, 241-152H

J.P. Morin, 719-4A

J.R. Fowler, 704-Z

D.D. Walker, 773-A

C.A. Nash, 773-43A

W.L. Tamosaitis, 773-A

M.J. Barnes, 773-A

R.F. Swingle, 773-A

S.D. Fink, 773-A

R.A. Peterson, 676-T

M.S. Miller, 704-72S

D.B. Amerine, 241-121H

M.D. Johnson, 704-56H

C.I. Crawford, 773-41A

M.L. Hyder, 773-A

W.R. Parish, 703-H

S.J. Eberlein, 241-121H

IWT Eile, 773-A

ITP Library, A.R. Lemay, 241-121H 
Figure 1. Blind standard analysis results

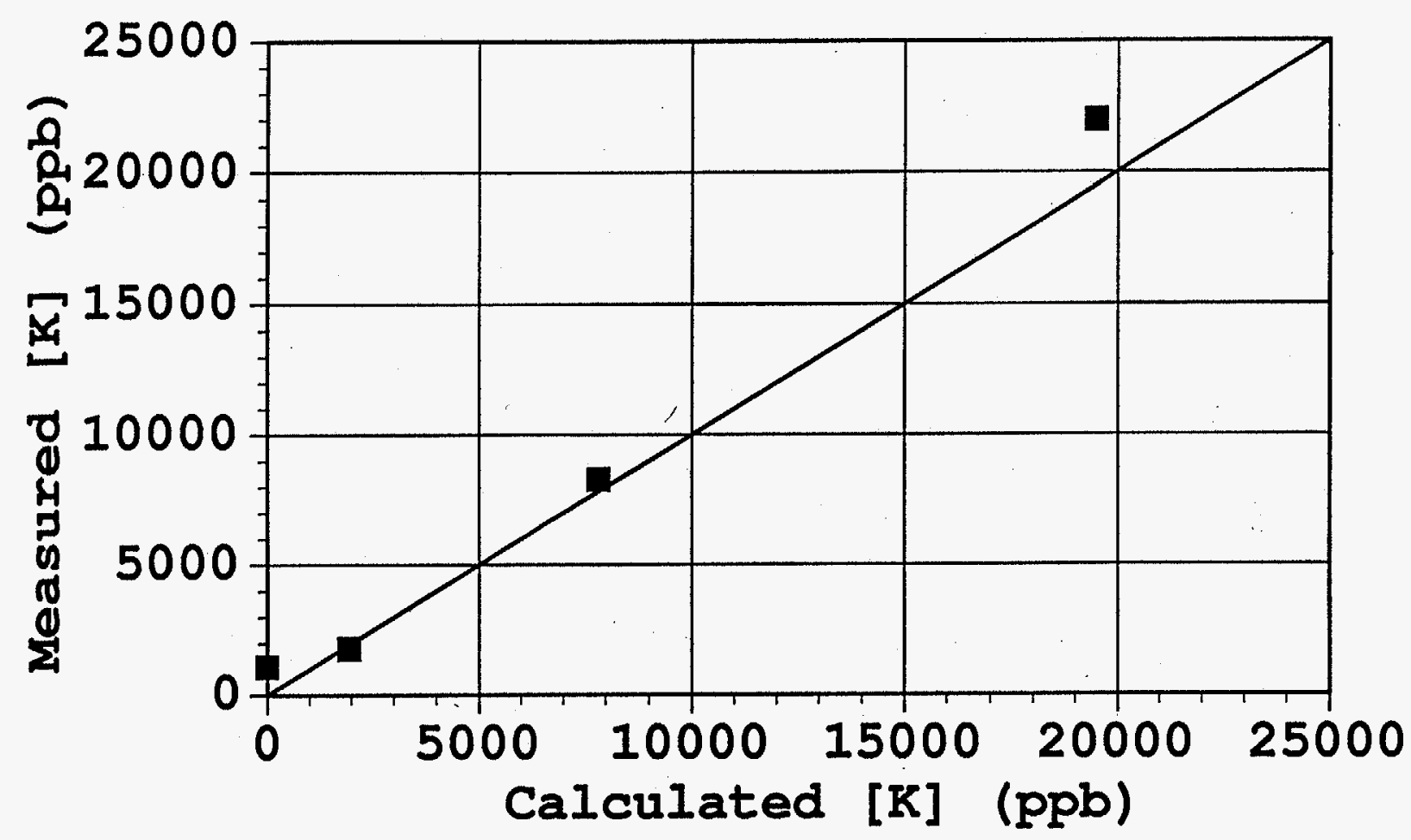


Figure 2. Blind Standard Cs Analysis Results

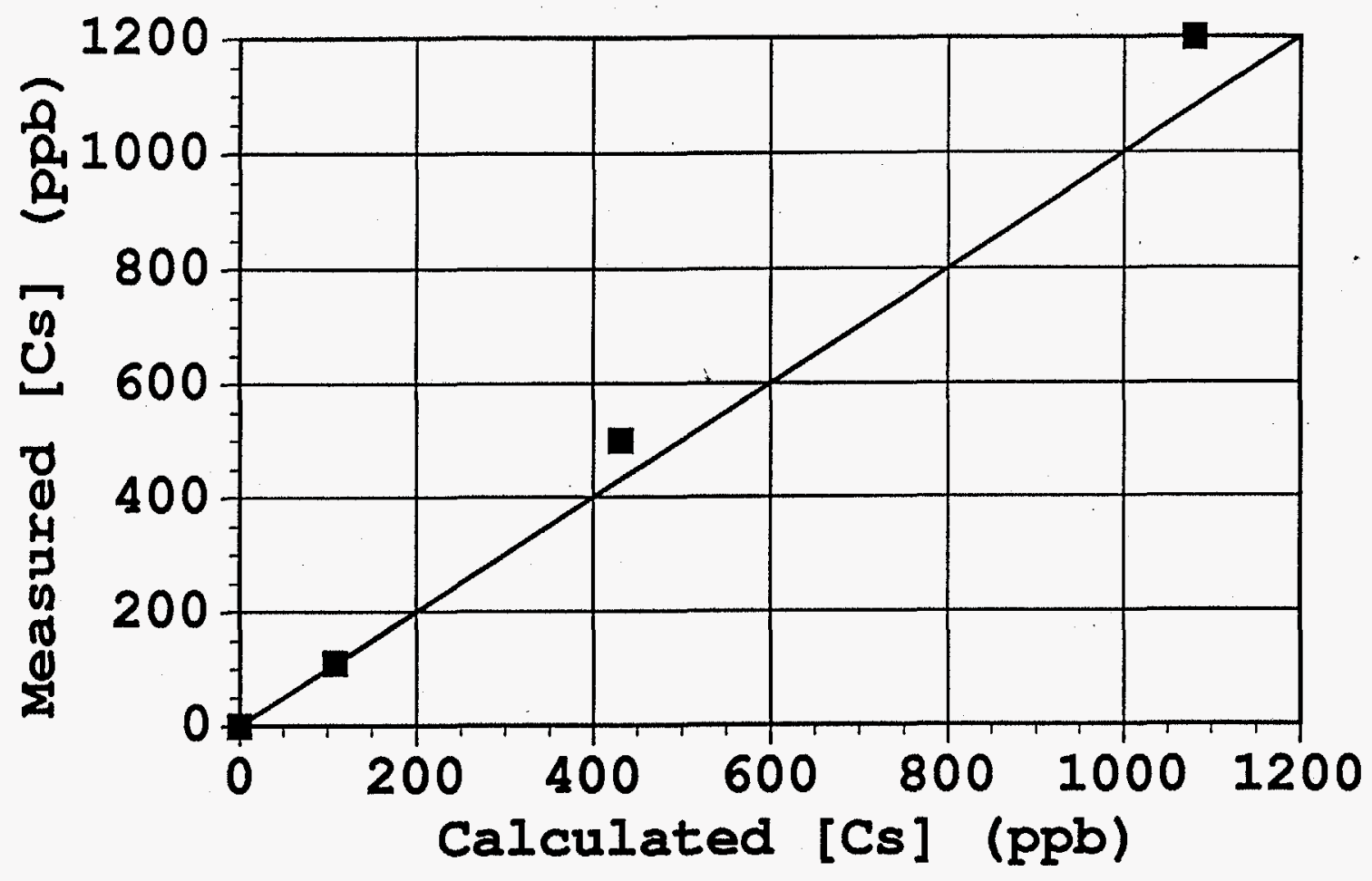


Figure 3. Density of Salt Solution

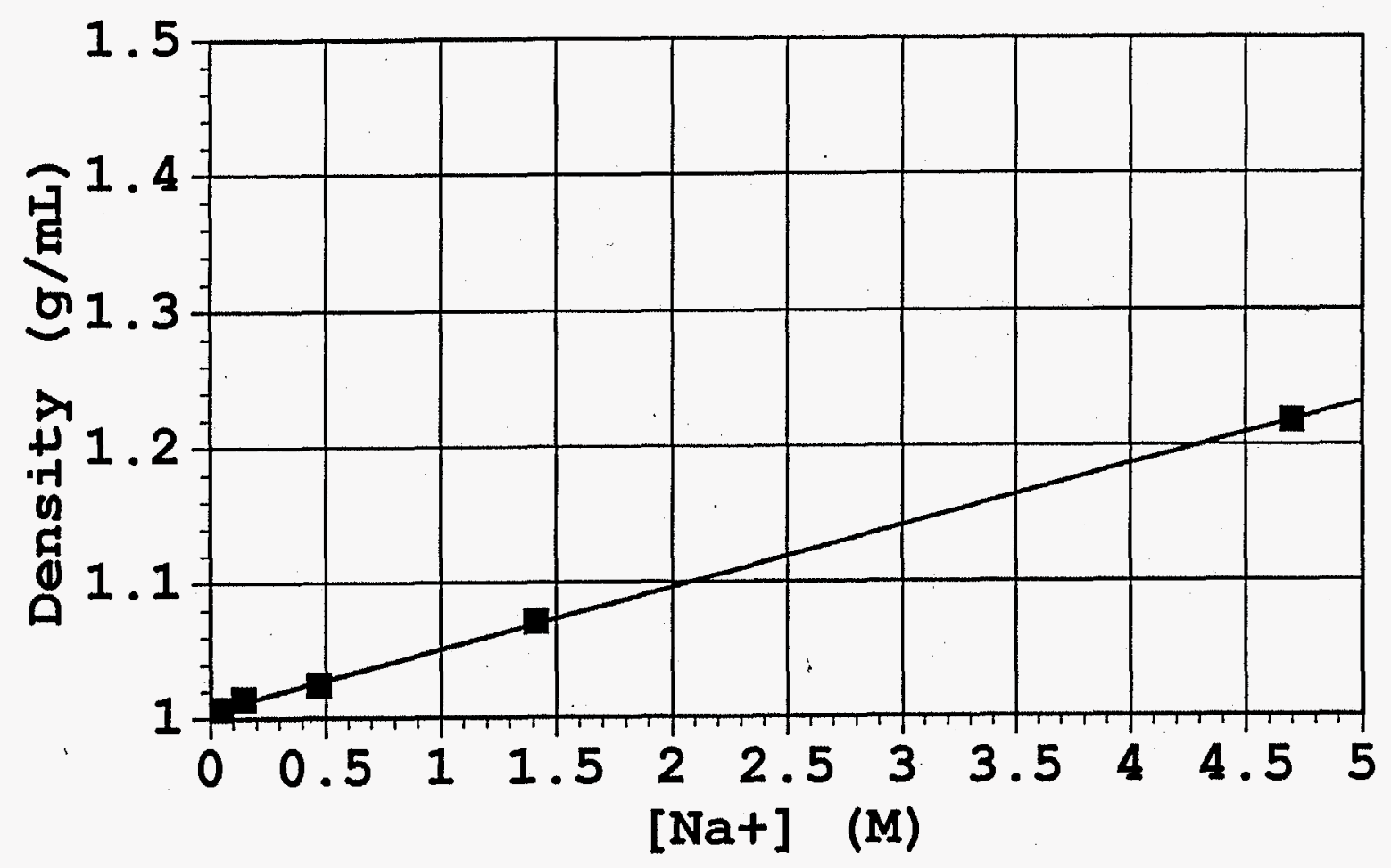

Density of standard salt solution

Density $=4.522 \mathrm{E}-2 *[\mathrm{Na}+]+1.006 \mathrm{E}+0$ 


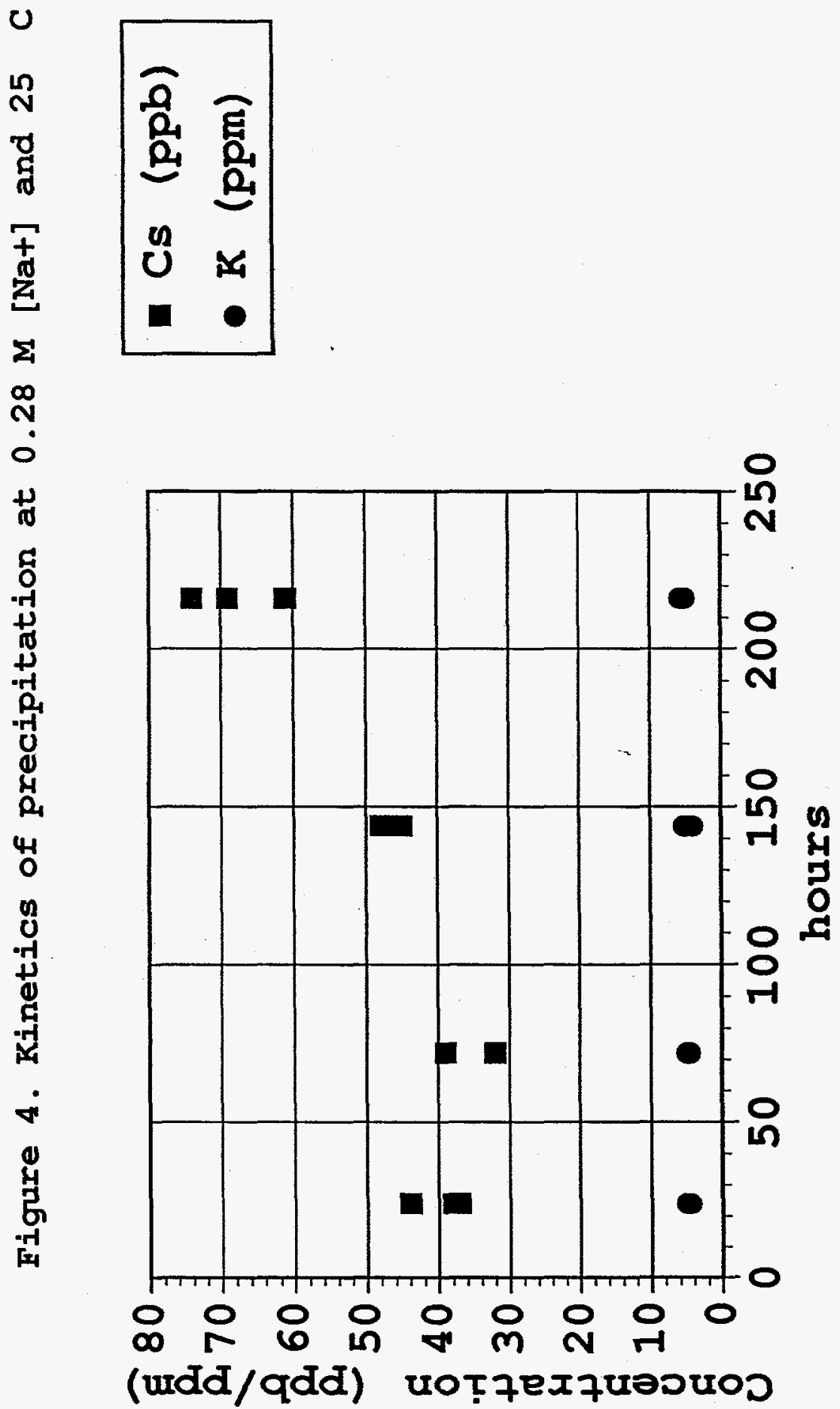


Figure 5. Near-stoichiometric STPB addition at 4.7

M. [Na+] Kinetics Test at 25 C

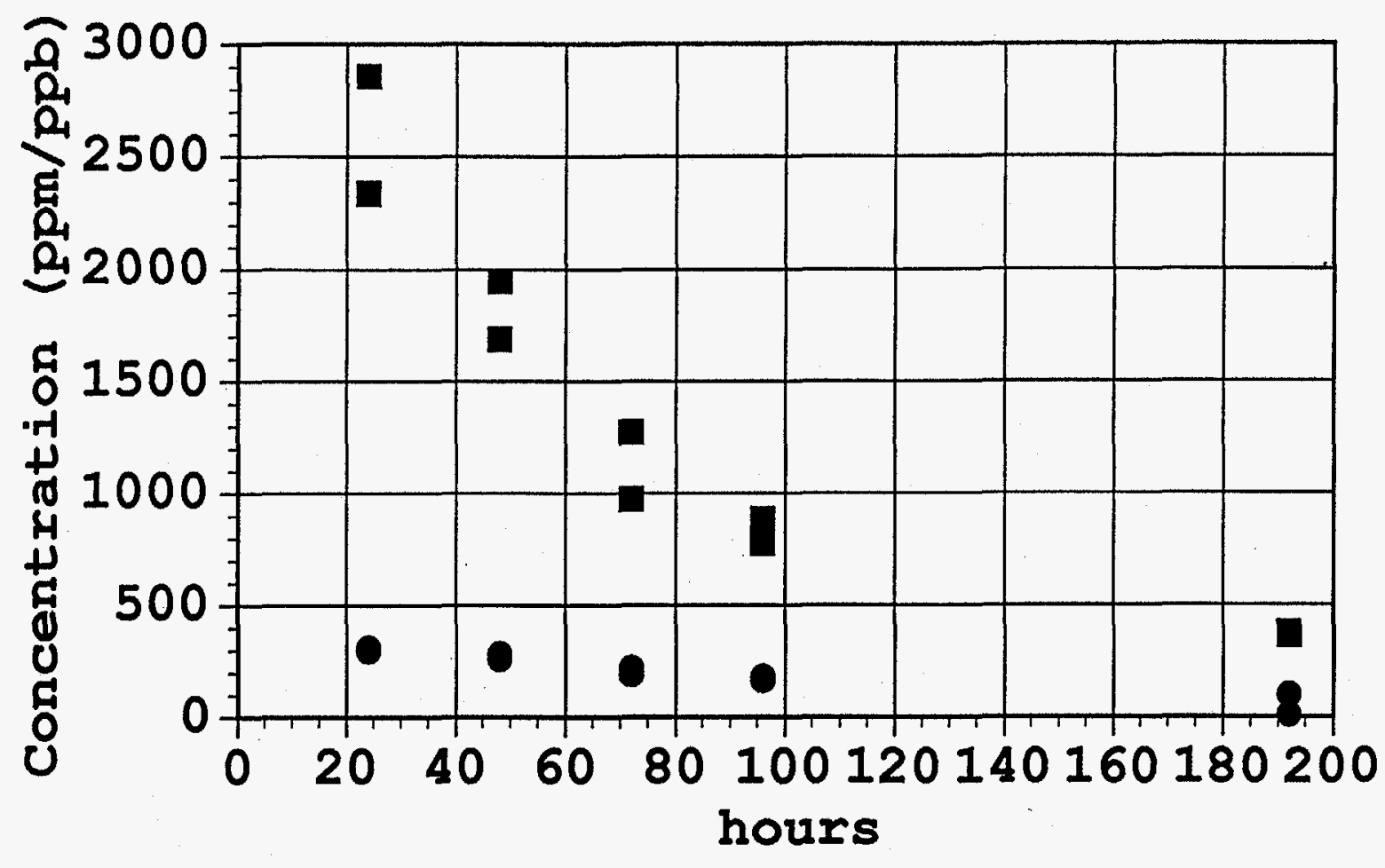

- Cs (ppb)

- $\mathrm{K}$ (ppm) 
Figure 6. Stoichiometric STPB Addition High

Temperature $(T=65$ C) Kinetics Test at $4.7 \mathrm{M}$ [Na+]

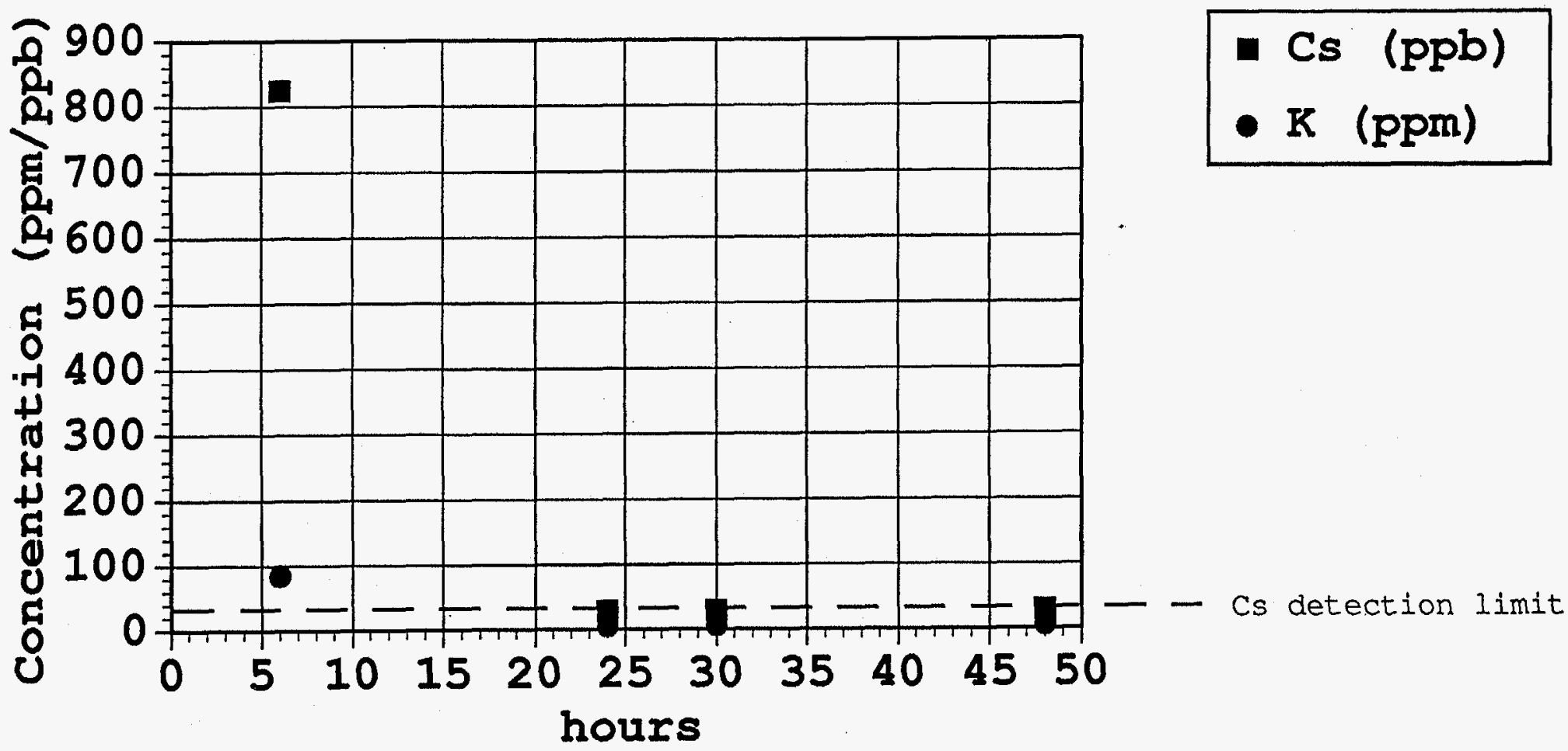




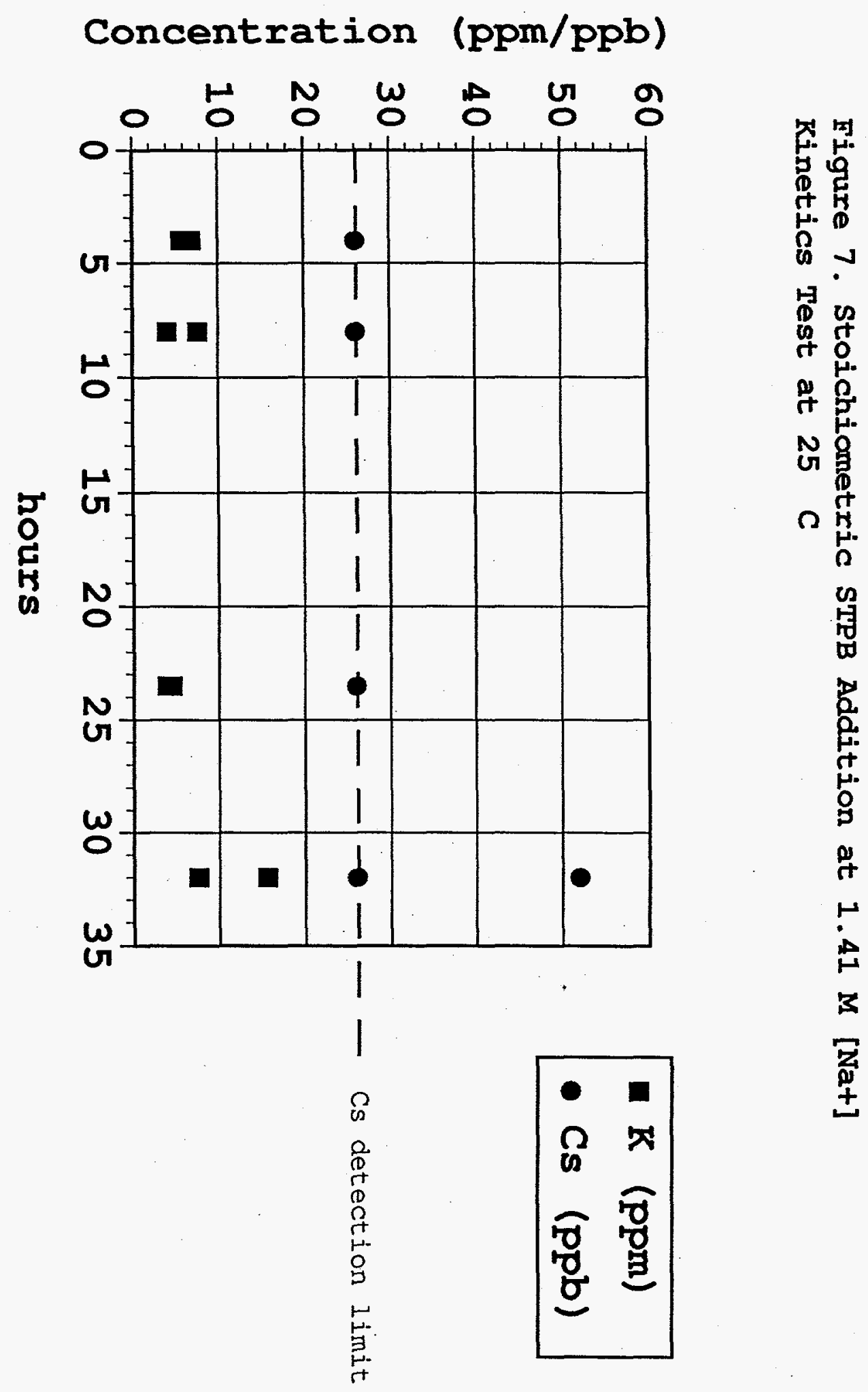


c

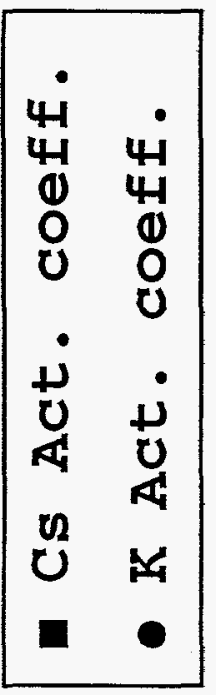

帒

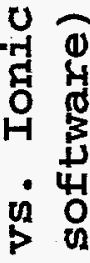

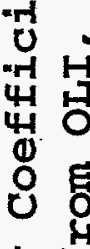

>ु

त

$\$ 0$

i⿱

A

है 岁

in

ข้

苟

क ज

영

त्व

占

d

ग्

$\infty$

\%

0 i

\& 4

5

|f

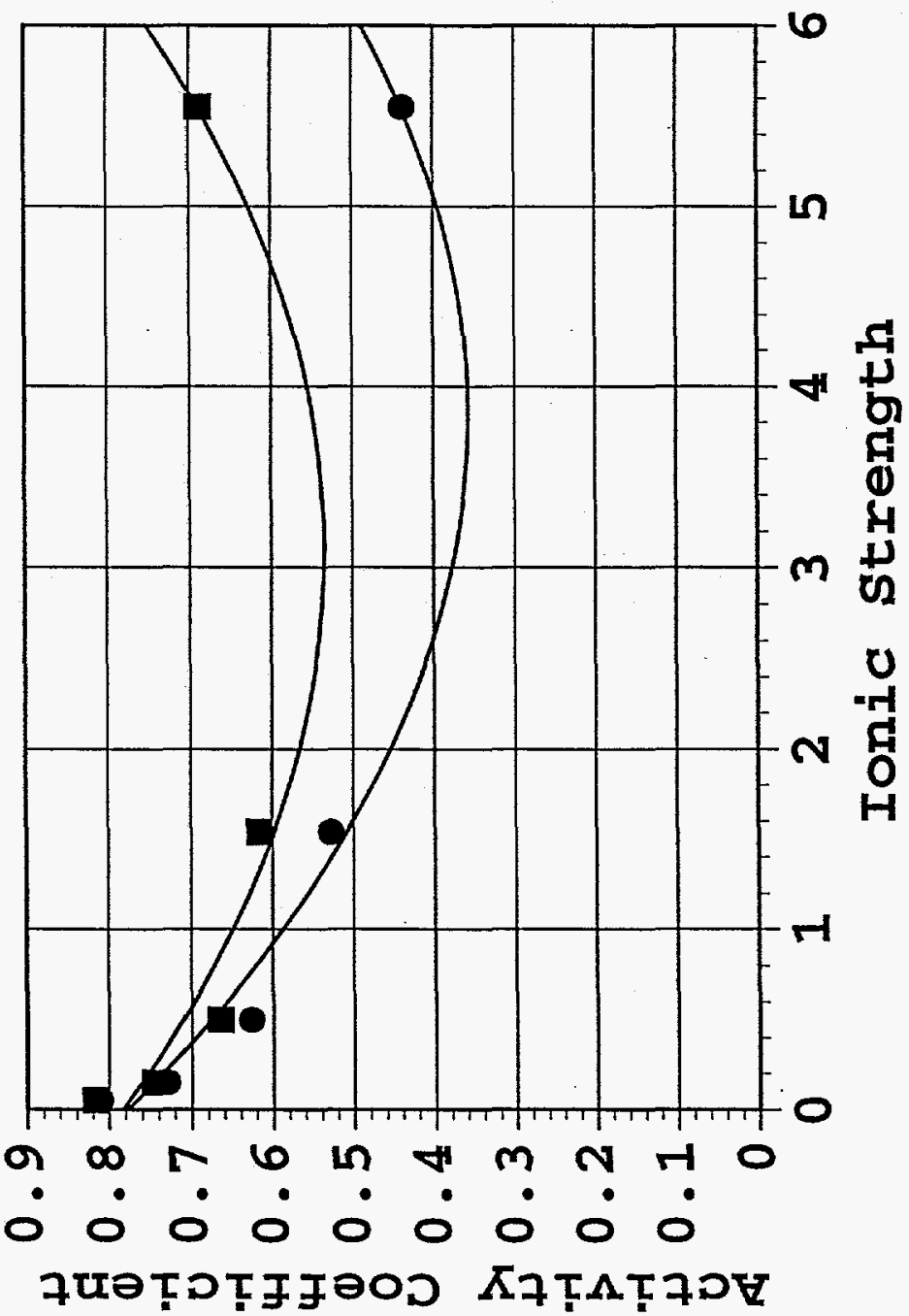

$$
\begin{aligned}
& 7 \\
& 1 \\
& \text { rn } \\
& m \\
& \infty \\
& \infty \\
& r
\end{aligned}
$$$$
\begin{array}{r}
7 \\
1 \\
r \\
ㄷ \\
ㄷ \\
\end{array}
$$$$
+
$$$$
\xi
$$$$
\stackrel{+}{*}
$$$$
\text { * }
$$$$
8
$$$$
\text { i }
$$$$
+
$$$$
\text { ? }
$$

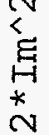

$\stackrel{*}{*}$

秀

in

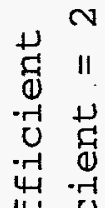

य -7 o

出

0 出 O

ते

3

$\rightarrow$ ते

$+4$

:

U U

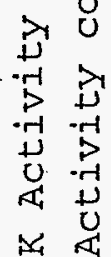

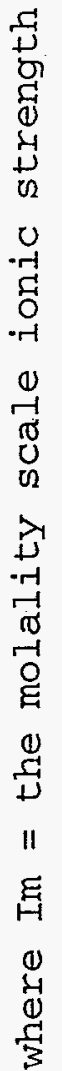


年

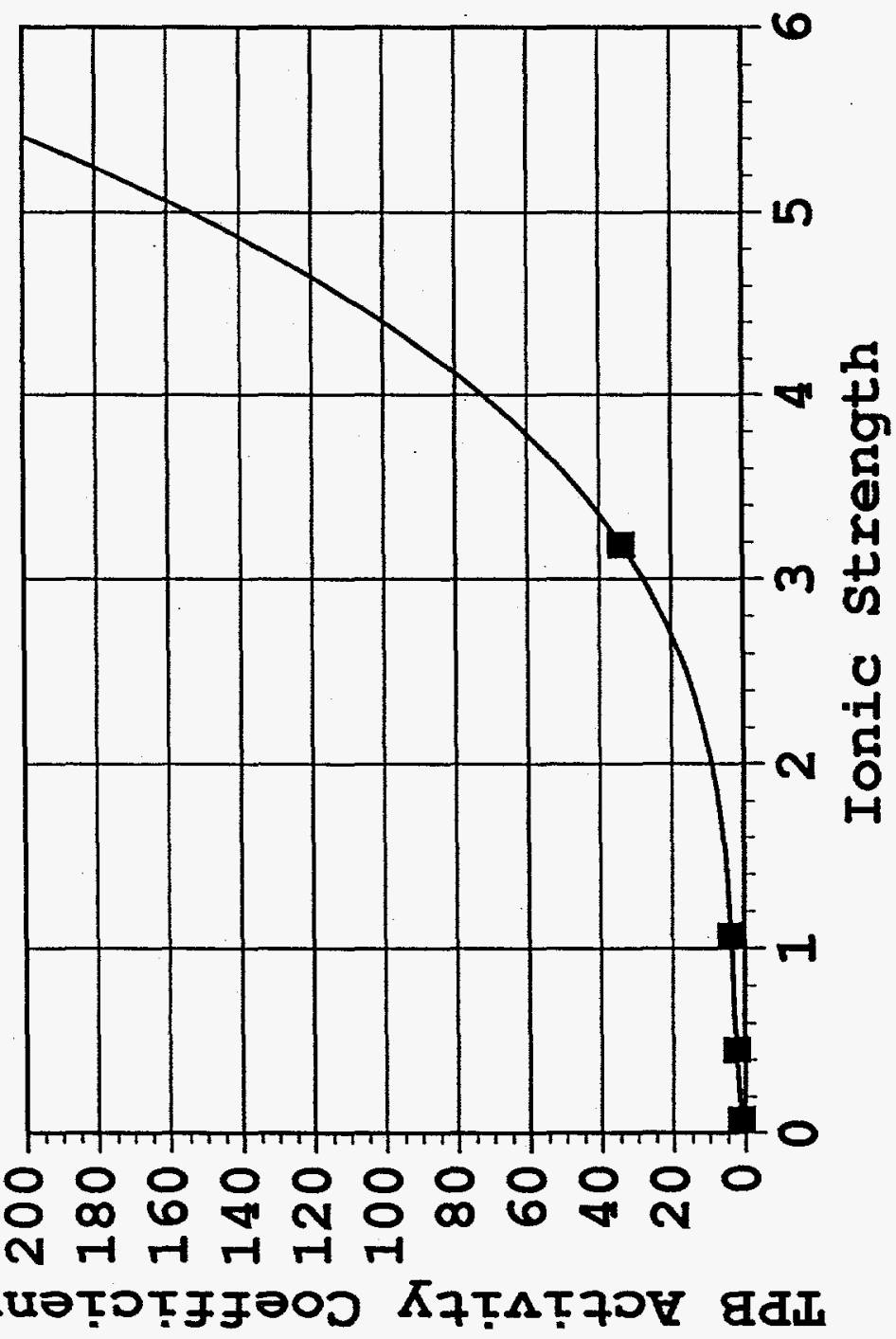

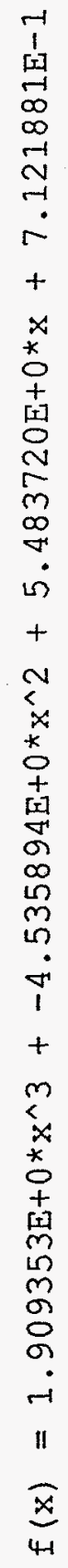

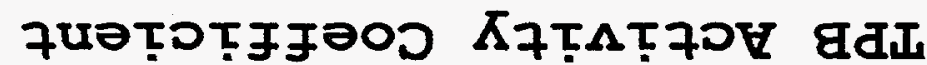




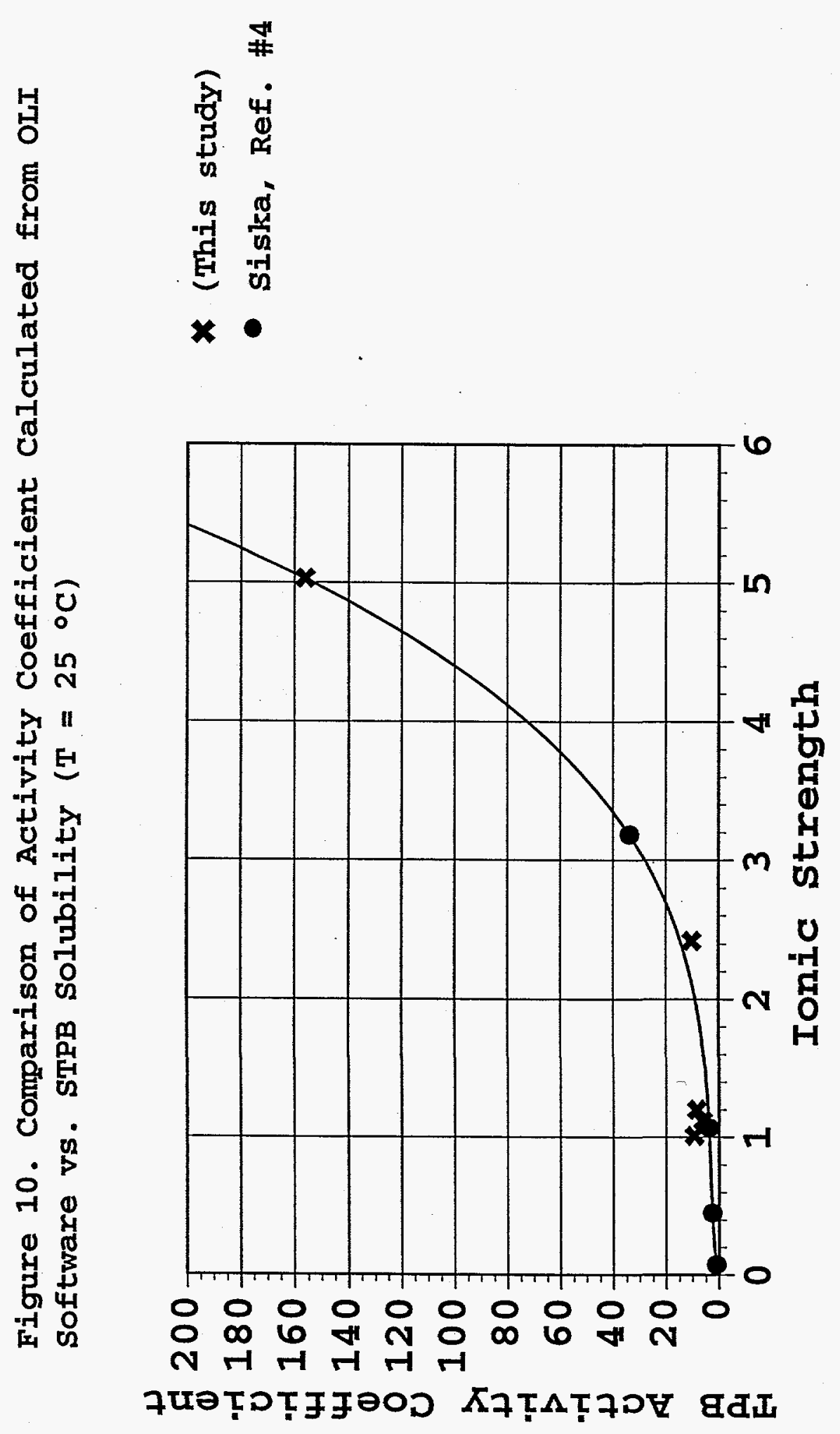




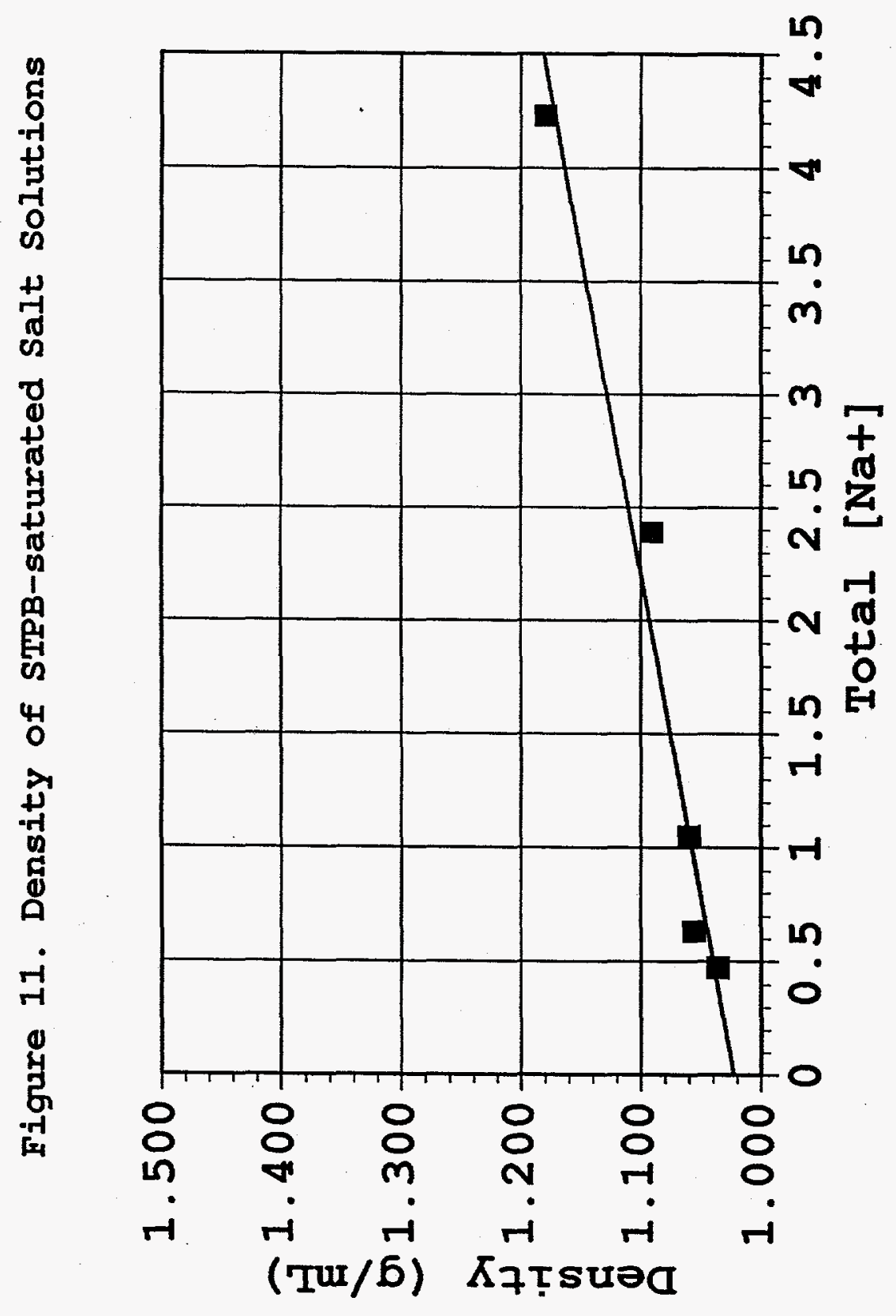



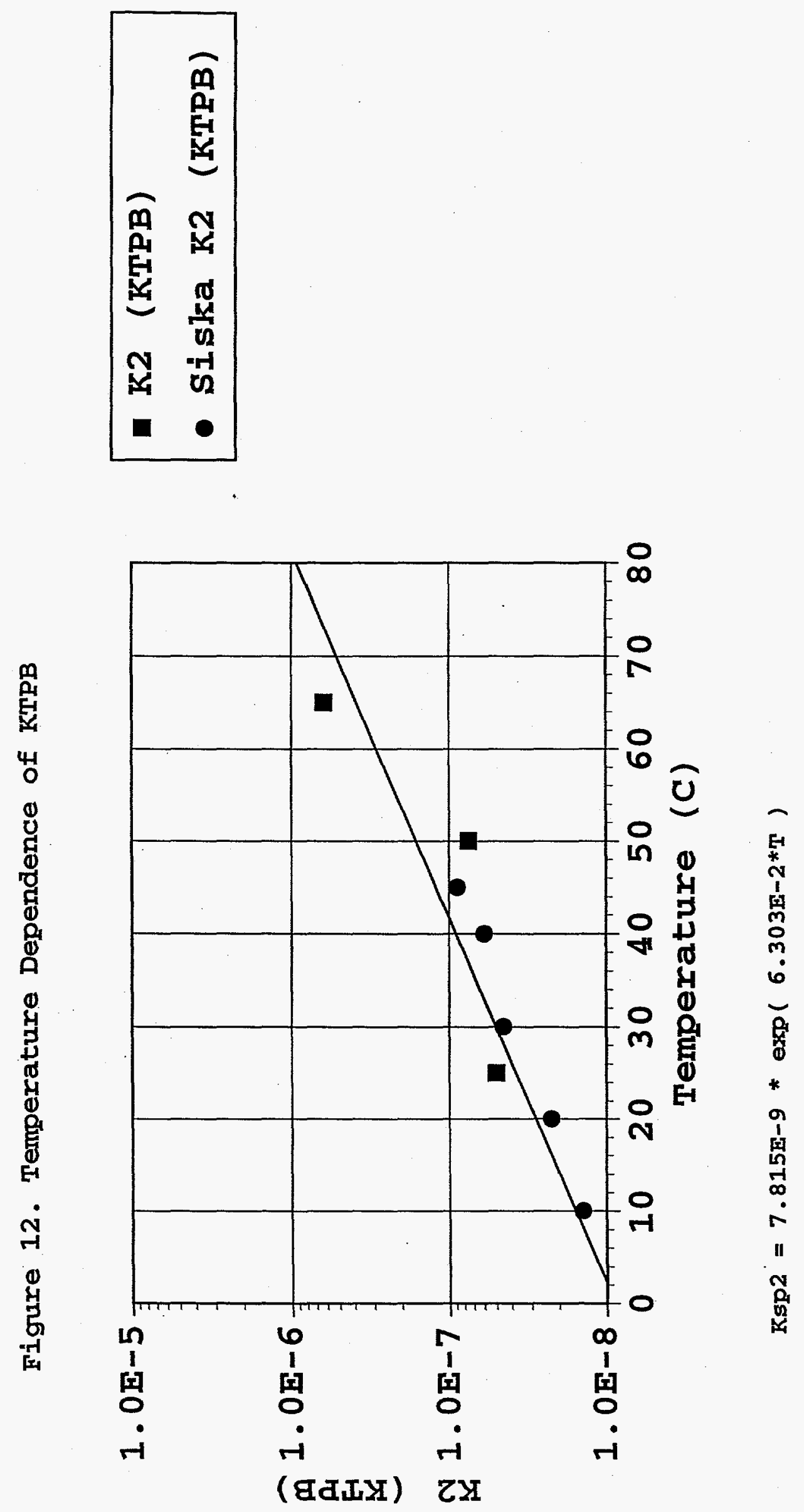


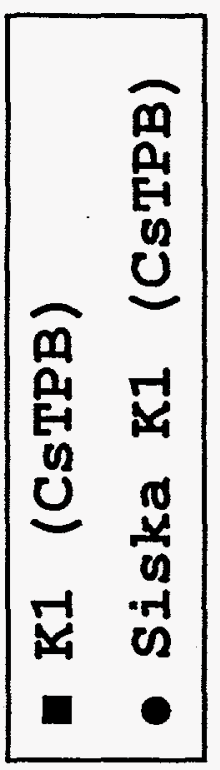

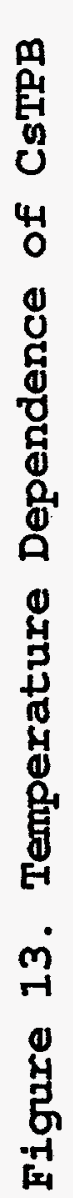

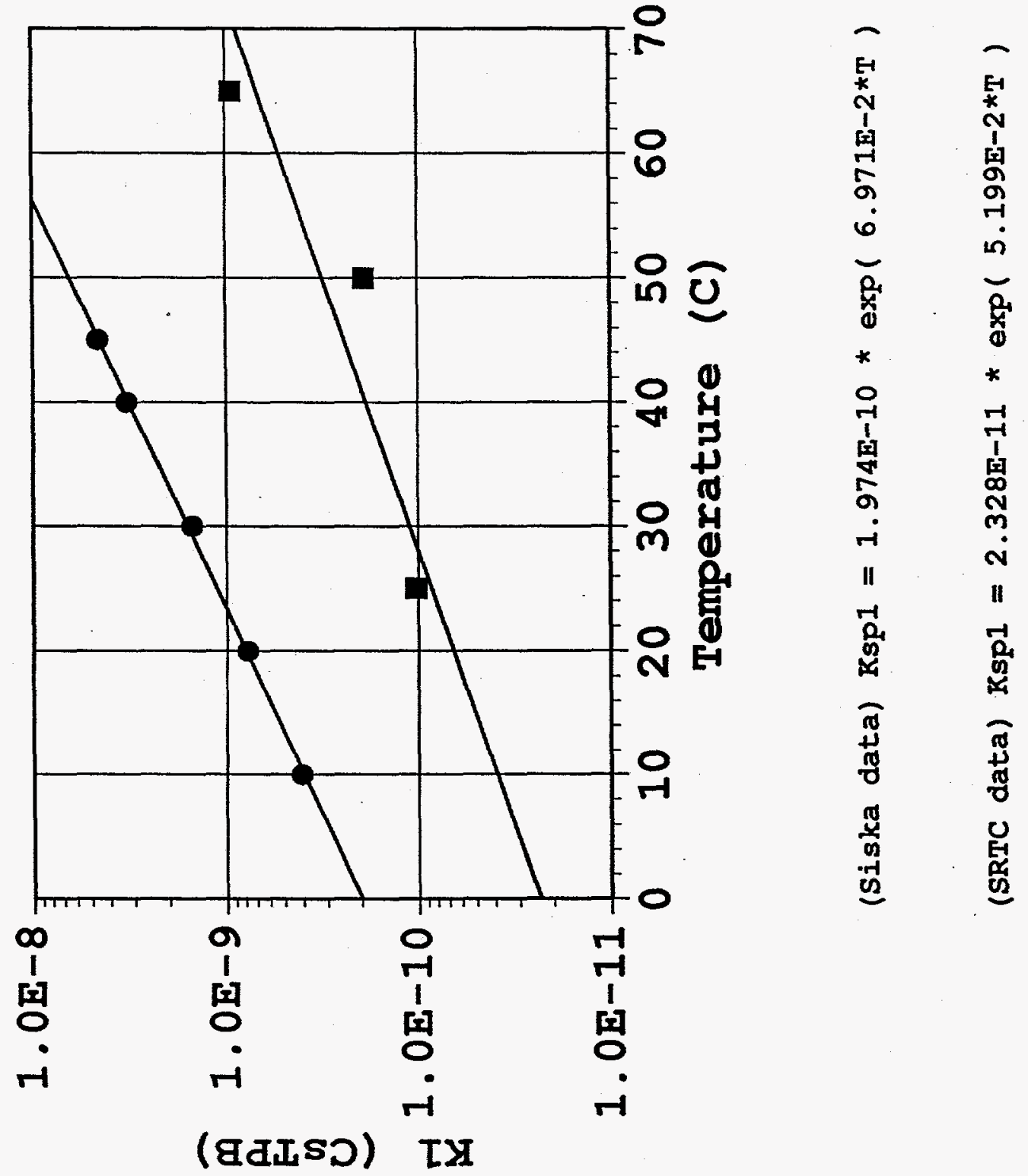


$m$

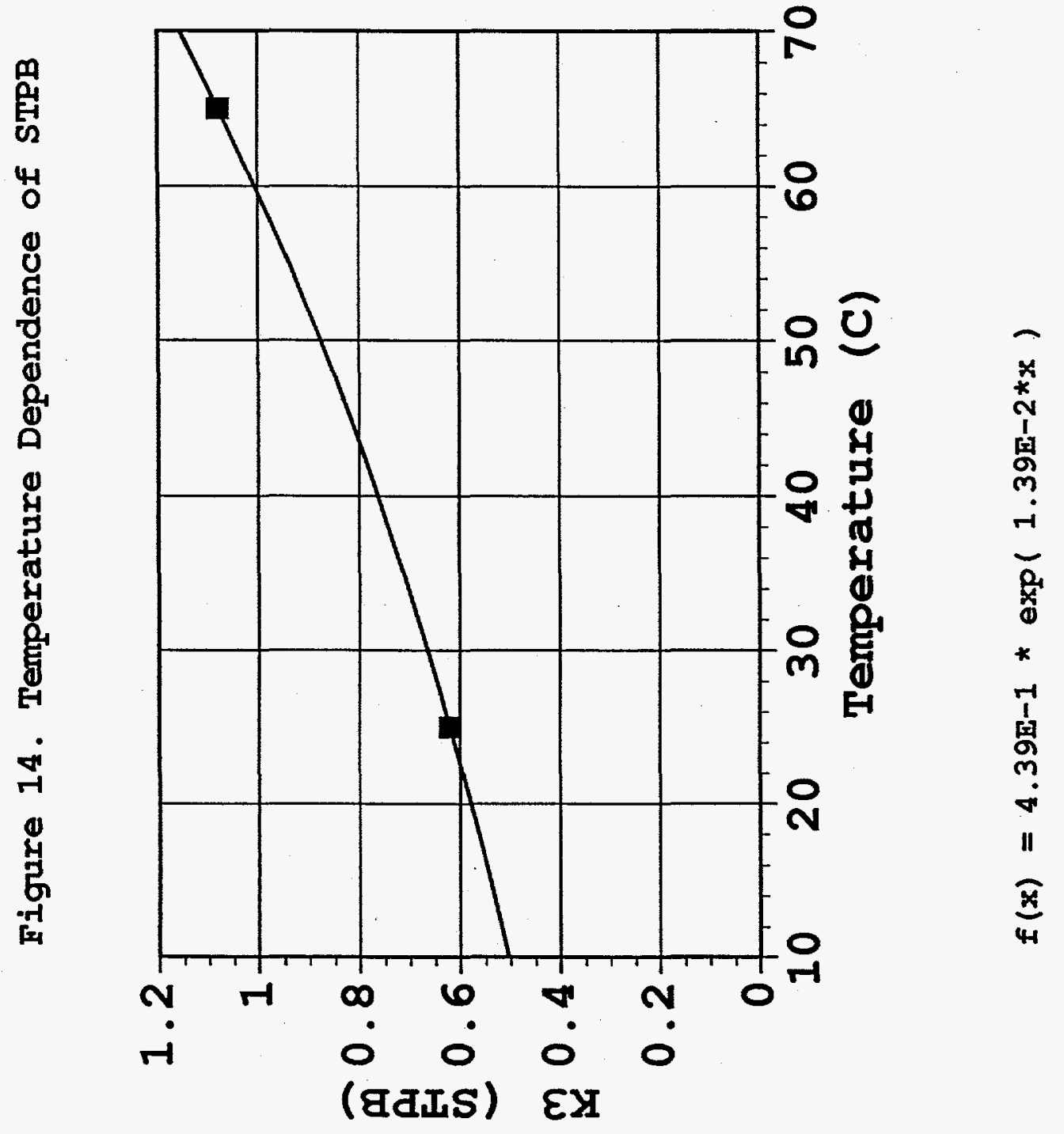




\begin{tabular}{|c|c|c|c|c|c|c|c|c|c|c|c|c|c|}
\hline \multicolumn{14}{|c|}{ Kinetics test blanks } \\
\hline & KIN-b-1 & KIN-b-2 & KIN-b-3 & KIN-b-4 & Avg. Init. ppb & Std. dev. & & & & & & & \\
\hline $\mathbf{B}$ & 230 & & \begin{tabular}{|r|}
700 \\
\end{tabular} & 780 & 570 & 297 & & & & & & & \\
\hline$K$ & 32000 & & 33000 & 33000 & 32667 & 577 & & & & & & & \\
\hline Cs & 1700 & & 1600 & 1800 & 1700 & 100 & & OLI-derive & d activity $\mathrm{c}$ & :oeff. from & Siska data & & \\
\hline \multicolumn{14}{|c|}{ Kinetics test } \\
\hline & KIN-1-24 & KIN-2-24 & $K I N-3-24$ & Avg. Init. ppb & Std. dev. & & Molarity & $\mathrm{Na}(\mathrm{M})$ & lon. Strength & Cs act. cooff & K act. coeff. & TPB act. coeff & $\mathbf{K}$ \\
\hline B & 2800 & 3100 & 3200 & 3033 & 208 & & 2.28E-04 & 0.28 & 0.3 & \begin{tabular}{|r|}
0.7372 \\
\end{tabular} & 0.7142 & 2.00 & \\
\hline $\mathbf{K}$ & 5000 & 4600 & 4600 & 4733 & 231 & & 1.21E-04 & & & & & & 3.94E-08 \\
\hline$\infty$ & 38 & 44 & 37 & 40 & 4 & & $2.98 E-07$ & & & & & & $1.00 \mathrm{E}-10$ \\
\hline \multicolumn{14}{|c|}{ Kinetics test } \\
\hline & KIN-1-72 & KIN-2-72 & KIN-3-72 & Avg. Init. ppb & Std. dev. & & & $\mathrm{Na}(\mathrm{M})$ & & & & & $\mathbf{k}$ \\
\hline B & 3200 & 3000 & & 3100 & 141 & & $2.34 E-04$ & 0.28 & 0.3 & 0.7372 & 0.7142 & 2.00 & \\
\hline $\mathbf{K}$ & 4600 & 4900 & & 4750 & 212 & & 1.21E-04 & & & & & & $4.06 \mathrm{E}-08$ \\
\hline$C_{s}$ & 32 & 39 & & 36 & 5 & & 2.67E-07 & & & & & & $9.21 E-11$ \\
\hline \multicolumn{14}{|c|}{ Kinetics test } \\
\hline$\therefore$ & KIN-1-144 & KIN-2-144 & KIN-3-144 & Avg. Init. ppb & Sid. dev. & & & $\mathrm{Na}(\mathrm{M})$ & & & & & $\mathbf{K}$ \\
\hline B & 2800 & 2800 & 3100 & 2900 & 173 & & $2.16 E-04$ & 0.28 & 0.3 & 0.7372 & 0.7142 & 2.00 & \\
\hline$\underline{\mathbf{K}}$ & 5300 & 5000 & 4100 & 4800 & 624 & & $1.23 \mathrm{E}-04$ & & & & & & $3.78 E-08$ \\
\hline$C_{8}$ & 45 & 45 & 48 & 46 & 2 & & $3.46 \mathrm{E}-07$ & & & & & & $1.10 E-10$ \\
\hline \multicolumn{14}{|c|}{ Kinetics tost } \\
\hline & KIN-1-216 & KIN-2-216 & KIN-3-216 & Avg. Init. ppo & Std. dev. & & & $\mathrm{Na}(\mathrm{M})$ & & & & & $\mathbf{K}$ \\
\hline $\mathbf{B}$ & 2900 & \begin{tabular}{|r|}
2800 \\
\end{tabular} & 3100 & 2933 & 153 & & $2.19 \mathrm{E}-04$ & 0.28 & 0.3 & 0.7372 & 0.7142 & 2.00 & \\
\hline $\mathbf{K}$ & 5700 & 5100 & 5600 & 5467 & 321 & & $1.40 E-04$ & & & & & & $4.36 E-08$ \\
\hline$C_{8}$ & 61 & 69 & 74 & 68 & 7 & & 5.12E-07 & & & & & & $1.65 E-10$ \\
\hline \multicolumn{14}{|c|}{ Washing/dilution test } \\
\hline & W/D-1-BLK & W/D-1-1 & W/D-1-2 & W/D-1-3 & Avg. final ppb & Std. dev. & & $\mathrm{Na}(\mathrm{M})$ & & Cs act. coeff & K act. coeff. & TPB act. coeff. & $\mathbf{K}$ \\
\hline $\mathbf{B}$ & 2100 & 560 & 540 & 520 & 540 & 20 & ??????m? & 4.7 & 5.55 & 0.6896 & 0.4419 & 217.76 & \\
\hline $\mathbf{K}$ & 560000 & 110000 & 98000 & 30000 & 7.9333 & 43143 & \multicolumn{2}{|c|}{ not at equilibrium } & & & & & \#VALUEI \\
\hline C8 & 31000 & 670 & 520 & 220 & 470 & 229 & \multicolumn{2}{|c|}{ not at equillbrium } & & & & & \#VALUE! \\
\hline \multicolumn{14}{|c|}{ Washing/dilution test } \\
\hline & W/D-2-BLK & W/D-2-1 & W/D-2-2 & W/D-2-3 & Avg. final ppob & Sid. dev. & & & & & & & \\
\hline $\mathbf{B}$ & 180 & $\begin{array}{r}1500 \\
\end{array}$ & 2100 & 2300 & 1967 & 416 & $1.65 \mathrm{E}-04$ & 1.41 & 1.54 & 0.5977 & 0.5086 & 5.37 & \\
\hline $\mathbf{K}$ & 170000 & 4900 & 4700 & 4300 & 4633 & 306 & $1.19 \mathrm{E}-04$ & & & & & & 5.35E-08 \\
\hline$\infty$ & 10000 & 40 & 20 & 20 & 27 & 12 & 2.01E-07 & & & & & & $1.06 \mathrm{E}-10$ \\
\hline \multicolumn{14}{|c|}{ Washing/dilution tesf } \\
\hline & W/D-3-BLK & W/D-3-1 & W/D-3-2 & W/D-3-3 & Avg. final ppb & Sid. dev. & & & & & & & \\
\hline B & $<100$ & 280 & 260 & 420 & 320 & 87 & 2.40E-05 & 0.47 & 0.5 & 0.7094 & 0.6751 & 2.56 & \\
\hline $\mathbf{K}$ & 260000 & 81000 & 76000 & 79000 & 78667 & 2517 & 2.01E-03 & & & & & & $8.35 E-08$ \\
\hline$\infty$ & 9700 & 410 & 460 & 510 & 460 & 50 & $3.46 \mathrm{E}-06$ & & & & & & $1.51 E-10$ \\
\hline \multicolumn{14}{|c|}{ Washing/dilution test } \\
\hline & WID-4-BLK & W/D-4-1 & W/D-4-2 & W/D-4-3 & Avg. final ppo & Std. dev. & & & & & & & \\
\hline $\mathbf{B}$ & $<100$ & 260 & 270 & 280 & 270 & 10 & 2.33E-05 & 0.14 & 0.15 & 0.7595 & 0.7449 & 1.44 & \\
\hline $\mathbf{K}$ & 170000 & 59000 & 59000 & 61000 & 59667 & 1155 & $1.53 E-03$ & & & & & & 3.81E-08 \\
\hline$C_{s}$ & 8200 & 470 & 520 & 520 & 503 & 29 & 3.79E-06 & & & & & & $9.65 \mathrm{E}-11$ \\
\hline \multicolumn{14}{|c|}{ Washing/dilution tes } \\
\hline & W/D-5-BLK & W/D-5-1 & W/D-5-2 & W/D-5-3 & Avg. final ppb & Sid. dev. & & & & & & & \\
\hline B & $<100$ & 270 & 260 & 210 & 247 & 32 & 2.23E-05 & 0.047 & 0.05 & 0.7750 & 0.7662 & 0.98 & \\
\hline
\end{tabular}




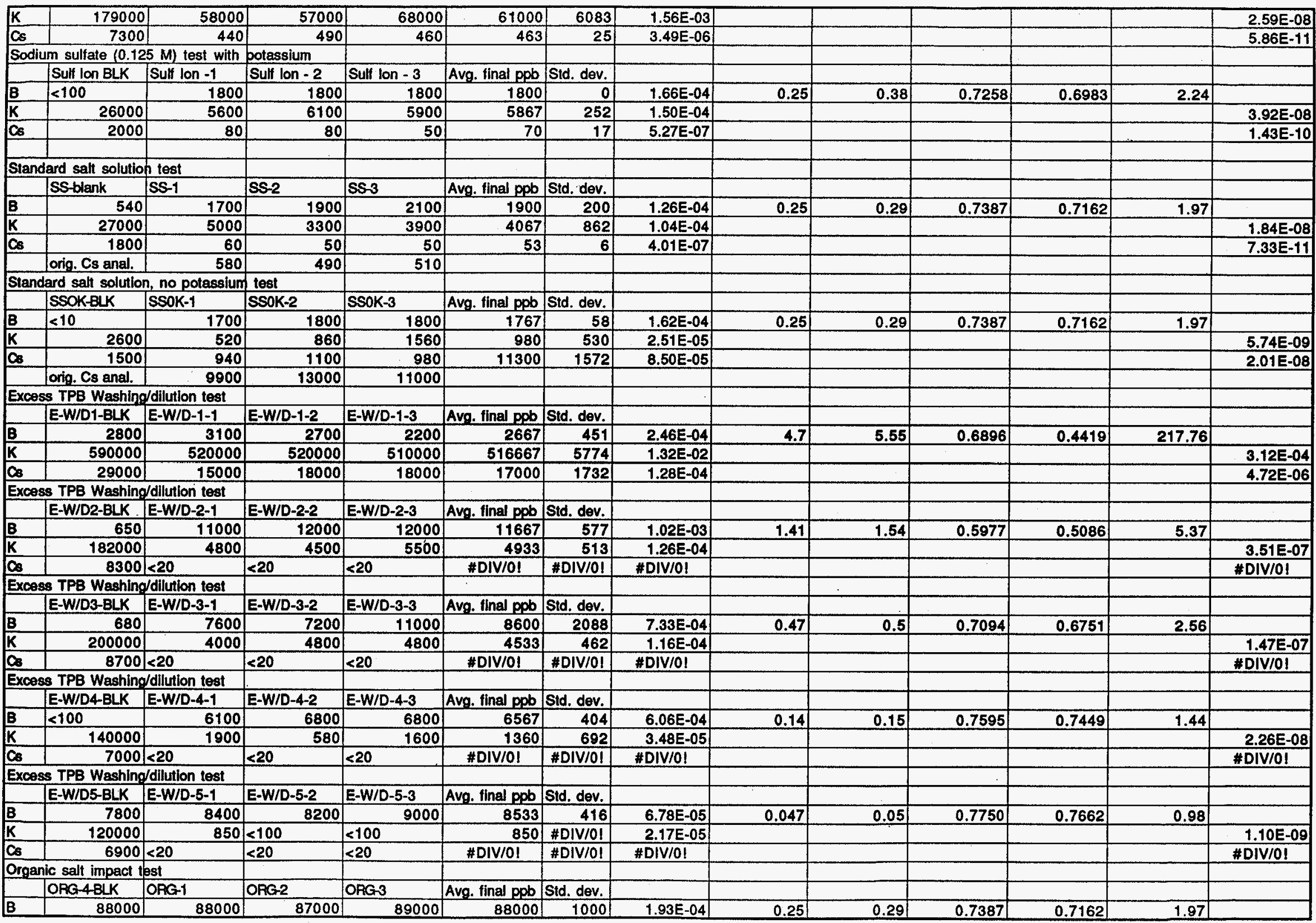




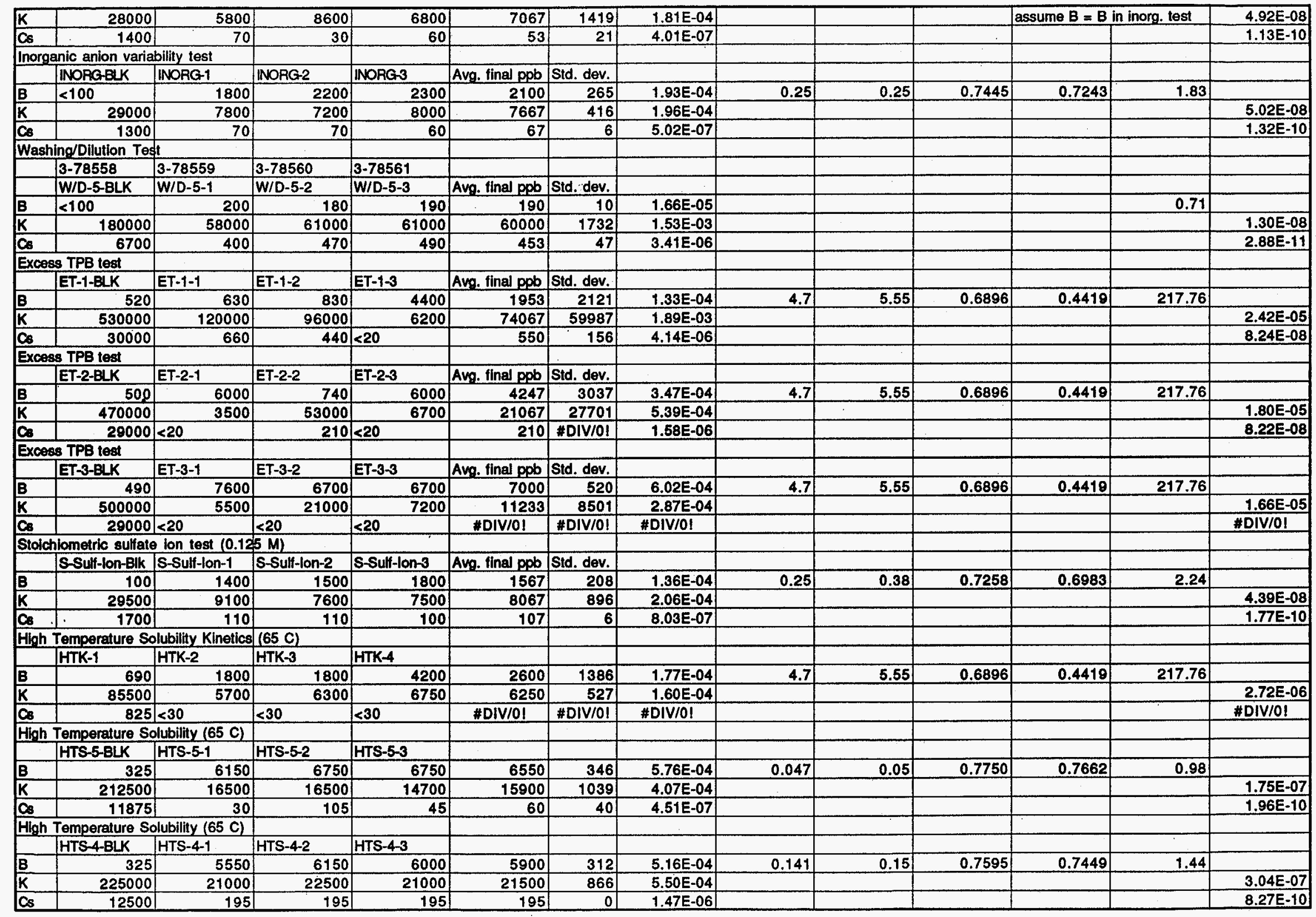




\begin{tabular}{|c|c|c|c|c|c|c|c|c|c|c|c|c|c|}
\hline \multicolumn{14}{|c|}{ High Temperature Solubility (65 C) } \\
\hline & HTS-3-BLK & HTS-3-1 & HTS-3-2 & HTS-3-3 & & & & & & & & & \\
\hline$B$ & 450 & 6300 & 6450 & 5400 & 6050 & 568 & $5.18 E-04$ & 0.47 & 0.5 & 0.7094 & 0.6751 & 2.56 & \\
\hline $\mathbf{K}$ & 262500 & 21000 & 21000 & 24000 & 22000 & 1732 & $5.63 \mathrm{E}-04$ & & & & & & 5.03E-07 \\
\hline$C_{s}$ & 16250 & 255 & 240 & 225 & 240 & 15. & $1.81 \mathrm{E}-06$ & & & & & & $1.70 \mathrm{E}-09$ \\
\hline \multicolumn{14}{|c|}{ High Temperature Solubility (65 C) } \\
\hline & HTS-2-BLK & HTS-2-1 & HTS-2-2 & HTS-2-3 & & & & & & & & & \\
\hline $\mathbf{B}$ & 250 & 4500 & 3900 & 4500 & 4300 & 346 & $3.75 \mathrm{E}-04$ & 1.41 & 1.54 & 0.5977 & 0.5086 & 5.37 & \\
\hline$\underline{K}$ & 300000 & 15000 & 11850 & 14850 & 13900 & 1777 & $3.56 \mathrm{E}-04$ & & & & & & $3.63 \mathrm{E}-07$ \\
\hline $\mathrm{Cs}_{3}$ & 17500 & 165 & 195 & 135 & 165 & 30 & $1.24 \mathrm{E}-06$ & & & & & & $1.49 E-09$ \\
\hline \multicolumn{14}{|c|}{ High Temperature Solubility (65 C) } \\
\hline & HTS-1-BLK & HTS-1-1 & HTS-1-2 & HTS-1-3 & & & & & & & & & \\
\hline B & 600 & 1650 & 3300 & 1245 & 2065 & 1089 & $1.36 \mathrm{E}-04$ & 4.7 & 5.55 & 0.6896 & 0.4419 & 217.76 & \\
\hline $\mathbf{K}$ & 412500 & 5250 & 4800 & 6000 & 5350 & 606 & 1.37E-04 & & & & & & $1.78 \mathrm{E}-06$ \\
\hline$C_{s}$ & 25000 & 5 & 2 & 2 & 3 & 2 & $2.26 \mathrm{E}-08$ & & & & & & $4.59 \mathrm{E}-10$ \\
\hline \multicolumn{14}{|c|}{ Intermediate Temperature Solubility $(50 \mathrm{C})$} \\
\hline & TTS-1-BLK & ITS-1-1 & ITS-1-2 & ITS-1-3 & & & & & & & & & \\
\hline$B$ & 2375 & 3750 & 3900 & 4500 & 4050 & 397 & $1.55 E-04$ & 0.47 & 0.5 & 0.7094 & 0.6751 & 2.56 & \\
\hline $\mathbf{K}$ & 287500 & 12450 & 10350 & 10200 & 11000 & 1258 & $2.81 E-04$ & & & & & & 7.52E-08 \\
\hline$C_{8}$ & 16250 & 90 & 105 & 75 & 90 & 15 & 6.77E-07 & & & & & & $1.90 \mathrm{E}-10$ \\
\hline \multicolumn{14}{|c|}{ Sodium sulfate $(0.125 \mathrm{M})$, no potassium } \\
\hline & SulfOK-BLK & SulfoK-1 & SulfoK-2 & SulfoK-3 & & & & & & & & & \\
\hline $\mathbf{B}$ & 180 & 420 & 600 & 310 & 443 & 146 & 2.44E-05 & 0.25 & 0.38 & 0.7258 & 0.6983 & 2.24 & \\
\hline $\mathbf{K}$ & $<100$ & 580 & 130 & 260 & 323 & 232 & 8.27E-06 & & & & & & $3.16 \mathrm{E}-10$ \\
\hline $\mathrm{CB}_{8}$ & 160000 & 7900 & 16700 & 11000 & 11867 & 4464 & $8.93 \mathrm{E}-05$ & & & & & & 3.54E-09 \\
\hline
\end{tabular}




\begin{tabular}{|c|c|c|c|c|c|c|c|c|c|c|}
\hline \multicolumn{11}{|c|}{ Kinetics Tests } \\
\hline & HIK-BLK-1 & HIK-BLK-2 & {$[\mathrm{Na}]=4.7 \mathrm{M}$} & & & & & & & \\
\hline $\mathrm{B}$ & 663 & 676 & & & & & & & & \\
\hline $\mathbf{K}$ & 728000 & 819000 & & & & & & & & \\
\hline \multirow[t]{3}{*}{ Cs } & 39000 & 46800 & & & & & & & & \\
\hline & & & & & & & & & & \\
\hline & HIK-1 & HIK-2 & HIK-3 & HIK-4 & HIK-5 & HIK-6 & HIK-7 & HIK-8 & HIK-9 & HIK-10 \\
\hline B & 559 & 546 & 585 & 598 & 559 & 572 & 559 & 572 & 559 & 585 \\
\hline $\mathbf{K}$ & 234000 & 234000 & 182000 & 234000 & 130000 & 143000 & 156000 & 156000 & 124800 & 122200 \\
\hline Cs & 1690 & 1950 & 1170 & 1430 & 689 & 702 & 806 & 767 & 520 & 637 \\
\hline hours & 48 & 48 & 72 & 72 & 144 & 144 & 192 & 192 & 240 & 240 \\
\hline \multicolumn{11}{|c|}{$\mathrm{K}$ (KTPB) } \\
\hline \multicolumn{11}{|c|}{$\mathrm{K}(\mathrm{CsTPB})$} \\
\hline & & & & & & & & & & \\
\hline \multirow{2}{*}{\multicolumn{2}{|c|}{ Stoichiometric TPB, moderate lonic strength kinetics test }} & & & & & & & & & \\
\hline & SMK-1 (blk) & SMK-2 (blk) & {$[\mathrm{Na}]=1.41 \mathrm{M}$} & & & & & & & \\
\hline $\mathbf{B}$ & - 78 & 39 & & & & & & & & \\
\hline $\mathbf{K}$ & 113100 & 88400 & & & & & & & & \\
\hline \multirow[t]{3}{*}{ Cs } & 7280 & 6370 & & & & & & & & \\
\hline & & & & & & & & & & \\
\hline & SMK-3 & SMK-4 & SMK-5 & SMK-6 & SMK-7 & SMK-8 & SMK-9 & SMK-10 & & \\
\hline B & 1820 & 1300 & 1690 & 2600 & 1820 & 1690 & 1001 & 988 & & \\
\hline $\mathrm{K}$ & 5720 & 6890 & 7670 & 4030 & 3900 & 4550 & 15600 & 7540 & & \\
\hline Cs & $<26$ & $<26$ & $<26$ & $<26$ & $<26$ & $<26$ & 52 & $<26$ & & \\
\hline hours & 4 & 4 & 8 & 8 & 23.5 & 23.5 & 32 & 32 & & \\
\hline & & & & & & & & & & \\
\hline & & & & & & & & & & \\
\hline & & & & & & & & & & \\
\hline \multicolumn{11}{|c|}{ Excess TPB High ionic strength Kinetics test (no blanks) } \\
\hline & EHK-1 & EHK-2 & EHK-3 & EHK-4 & EHK-5 & EHK-6 & EHK-7 & EHK-8 & EHK-9 & EHK-10 \\
\hline B & 663 & 572 & 546 & 520 & 520 & 520 & 520 & 533 & 520 & 507 \\
\hline $\mathrm{K}$ & 299000 & 312000 & 260000 & 286000 & 221000 & 195000 & 169000 & 182000 & 9880 & 102700 \\
\hline Cs & 2860 & 2340 & 1690 & 1950 & 1274 & 975 & 780 & 884 & 377 & 364 \\
\hline hours & 24 & 24 & 48 & 48 & 72 & 72 & 96 & 96 & 192 & 192 \\
\hline
\end{tabular}




\begin{tabular}{|c|c|c|c|c|c|c|c|c|c|c|c|}
\hline \multicolumn{12}{|c|}{ Sodium Tetraphenylborate solubility } \\
\hline & & dil'n corrected & & dil'n corrected & & dil'n corrected & & dil'n corrected & & & \\
\hline & SNA-1-BLK & SNA1-BLK & SNA-1-1 & SNA1-1 & SNA-1-2 & SNA1-2 & SNA-1-3 & SNA1-3 & Average & {$[\mathrm{B}$ or $\mathrm{Na}](\mathrm{M})$} & init. $[\mathrm{Na}](\mathrm{M})$ \\
\hline B & $<0.5$ & \#VALUE! & $<0.5$ & \#VALUE! & $<0.5$ & \#VALUE! & $<0.5$ & \#VALUE! & \#VALUEI & \#VALUE! & \\
\hline \multirow[t]{3}{*}{$\mathrm{Na}$} & 95250 & 100012.5 & 93960 & 103356 & 91140 & 100254 & 89870 & 98857 & 100822 & 4.386 & 4.700 \\
\hline & & & & & & & & & & & \\
\hline & SNA-2-BLK & SNA2-BLK & SNA-2-1 & SNA2-1 & SNA-2-2 & SNA2-2 & SNA-2-3 & SNA2-3 & & & \\
\hline $\mathbf{B}$ & $<0.5$ & \#VALUEI & 351 & 386.1 & 440 & 484 & 488 & 536.8 & 469. & 0.043 & \\
\hline \multirow[t]{3}{*}{$\mathrm{Na}$} & 51280 & 53844 & 44810 & 49291 & 42980 & 47278 & 44180 & 48598 & 48389. & 2.105 & 2.350 \\
\hline & & & & & & & & & & & \\
\hline & SNA-3-BLK & SNAB-BLK & SNA-3-1 & SNA3-1 & SNA-3-2 & SNAB-2 & SNA-3-3 & SNA3-3 & & & \\
\hline$B$ & 1672 & 1755.6 & 1738 & 1911.8 & 756 & 831.6 & 791 & 870.1 & 1205. & 0.111 & \\
\hline \multirow[t]{3}{*}{$\mathrm{Na}$} & 20280 & 21294 & 21810 & 23991 & 22380 & 24618 & 23270 & 25597 & 24735. & 1.076 & 0.940 \\
\hline & & & & & & & & & & & \\
\hline & SNA-4-BLK & SNA4-BLK & SNA-4-1 & SNA4-1 & SNA-4-2 & SNA4-2 & SNA-4-3 & SNA4-3 & & & \\
\hline $\bar{B}$ & 108 & 113.4 & 1.617 & 1778.7 & 1775 & 1952.5 & 1711 & 1882.1 & 1871. & 0.163 & \\
\hline \multirow[t]{3}{*}{$\mathrm{Na}$} & 10970 & 11518.5 & 17930 & 19723 & 18080 & 19888 & 18100 & 19910 & 19840. & 0.863 & 0.470 \\
\hline & & & & & & & & & & & \\
\hline & SNA-5-BLK & SNA5-BLK & SNA-5-1 & SNA5-1 & SNA-5-2 & SNA5-2 & SNA-5-3 & SNA6-3 & & & \\
\hline B & 210 & 220.5 & 3262 & 3588.2 & 3477 & 3824.7 & 3628 & 3990.8 & 3801. & 0.332 & \\
\hline \multirow[t]{3}{*}{$\mathrm{Na}$} & 2893 & 3037.65 & 18490 & 20339 & 17160 & 18876 & 17700 & 19470 & 19562. & 0.851 & 0.141 \\
\hline & & & & & & & & & & & \\
\hline & SNA-6-BLK & SNA6-BLK & SNA-6-1 & SNA6-1 & SNA-6-2 & SNA-6-2 & SNA-6-3 & SNA6-3 & & & \\
\hline$B$ & 0.1 & 0.11 & 15 & $\begin{array}{r}16.5 \\
\end{array}$ & 16.8 & 18.48 & $\begin{array}{r}16.9 \\
\end{array}$ & \begin{tabular}{|r|}
18.59 \\
\end{tabular} & 18. & 0.0016 & \\
\hline $\mathrm{Na}$ & & 0 & & 0 & & 0 & & 0 & 0. & 4.230 & 4.230 \\
\hline \multicolumn{3}{|c|}{ Sodium tetraphenylborate solubility at $65 \mathrm{C}$} & , & & & & & & & & \\
\hline & SNA-7-BLK & SNA7-BLK & SNA-7-1 & SNA7-1 & SNA-7-2 & SNA-7-2 & SNA-7-3 & SNA7-3 & & & \\
\hline $\mathbf{B}$ & 0 & 0 & 244.6 & 366.9 & 295.1 & 442.65 & 285.1 & 427.65 & 412. & 0.0381 & \\
\hline $\mathrm{Na}$ & & 0 & & 0 & & 0 & & 0 & 0.1 & & 2.350 \\
\hline
\end{tabular}




\begin{tabular}{|c|c|c|c|c|c|c|c|c|c|c|}
\hline & & & & & & & & & & \\
\hline & . & & & & & & & & & Assume $\mathrm{K} 3=0$ \\
\hline calc'd $\mathrm{Na}(\mathrm{M})$ & density $(\mathrm{g} / \mathrm{mL}$ & wt. diss. solid & Na molality & [monoanion]m & [div.anion] $m$ & Ionic Str. I & $\mathrm{Na}$ act. coeff. & TPB act.coeff. & $\mathrm{K} 3$ & TPB act. coeff \\
\hline & 1.210 & 321.70 & 4.935 & 4.315 & 0.310 & 5.25 & 0.575 & 180.19 & \#VALUE! & \#VALUE! \\
\hline \multirow{2}{*}{\multicolumn{11}{|c|}{4.700}} \\
\hline & & & & & & & & & & \\
\hline & 1.091 & 160.85 & 2.262 & 1.947 & 0.158 & 2.42 & 0.583 & 14.46 & 0.87500962 & 10.25 \\
\hline \multirow{2}{*}{\multicolumn{11}{|c|}{2.393}} \\
\hline & & & & & & & & & & \\
\hline & 1.060 & 110.86 & 1.134 & 0.995 & 0.069 & 1.20 & 0.629 & 4.06 & 0.29937626 & 8.41 \\
\hline \multirow{2}{*}{\multicolumn{11}{|c|}{1.051}} \\
\hline & & & & & & & & & & \\
\hline & & & & & & & & & & \\
\hline & 1.056 & 166.67 & 0.971 & 0.887 & 0.042 & 1.01 & 0.639 & 3.59 & 0.23678322 & 9.40 \\
\hline \multicolumn{11}{|l|}{0.633} \\
\hline & & & & & & & & & & \\
\hline & 1.036 & 252.59 & 1.086 & 1.024 & 0.031 & 1.12 & 0.634 & 3.83 & 0.38158316 & 6.22 \\
\hline \multirow{2}{*}{\multicolumn{11}{|c|}{0.473}} \\
\hline & & & & & & & & & & \\
\hline & & & & & & & & & & \\
\hline & 1.179 & 289.53 & 4.755 & 4.196 & 0.279 & 5.03 & 0.571 & 156.87 & 0.62268052 & 156.18 \\
\hline \multicolumn{11}{|l|}{4.232} \\
\hline & & & & & & & & & & \\
\hline & 1.104 & 173.90 & 2.568 & 2.253 & 0.158 & 2.73 & 0.575 & 20.58 & $\mid 1.07886777$ & 11.83 \\
\hline 2.388 & & & & & & & & ED TEM & PERATURE EXP & \\
\hline
\end{tabular}

